\title{
The Effect of Neutral Oximes on the Reactivation of Human Acetylcholinesterase Inhibited with Paraoxon
}

\author{
Tatiana S. Ribeiro, ${ }^{a}$ Arthur Prates, ${ }^{b}$ Sérgio R. Alves, ${ }^{b}$ Jefferson J. Oliveira-Silva, ${ }^{b}$ \\ Carlos A. S. Riehl ${ }^{c}$ and J. Daniel Figueroa-Villar*,a
}

${ }^{a}$ Departamento de Química, Instituto Militar de Engenharia, Praça General Tibúrcio, 80, Praia Vermelha, 22290-270 Rio de Janeiro-RJ, Brazil

${ }^{b}$ Centro de Estudos da Saúde do Trabalhador e Ecologia Humana (CESTEH), ENSP, Fiocruz, Rua Leopoldo Bulhões, 1480, Manguinhos, 21041-210 Rio de Janeiro-RJ, Brazil

'Instituto de Química, Universidade Federal do Rio de Janeiro, Ilha do Fundão, Rio de Janeiro-RJ, Brazil

Importantes agentes para defesa contra armas de guerra química são reativadores da acetilcolinesterase humana (huAChE) inibida por compostos organofosforados neurotóxicos (OP), e precisam de uma permeabilidade razoável pela barreira hematoencefálica (HB). Neste trabalho, oximas neutras, que penetram $\mathrm{HB}$ melhor do que as oximas catiônicas atualmente utilizadas como agentes de defesa, foram testadas como reativadores da huAChE inibida com paraoxon usando o método de Ellman modificado e pralidoxima (2-PAM) como padrão positivo. A oxima neutra mais ativa foi a 2-tiofenoaldoxima, que reativou $93 \%$ da huAChE inibida, sendo $12 \%$ mais eficiente do que a 2-PAM. Os resultados mostraram que oximas neutras simples possuem potencial para atuarem como antídotos para intoxicação com OPs neurotóxicos, sugerindo maior investigação no desenvolvimento de agentes de defesa neutros.

\begin{abstract}
Important defense agents against chemical warfare weapons, which are reactivators of human acetylcholinesterase (huAChE) inhibited by neurotoxic organophosphorus compounds (OP), need a reasonable permeation of the hematoencephalic barrier (HB). In this work, neutral oximes, which permeate $\mathrm{HB}$ better than the cationic oximes currently used as defense agents, were tested as reactivators of huAChE inhibited with paraoxon using the modified Ellman test with pralidoxime (2-PAM) as positive standard. The most active neutral oxime was (thiophen-2-yl)aldoxime, which reactivated $93 \%$ of the inhibited huAChE and was $12 \%$ more effective than 2-PAM. The results showed that simple neutral oximes have potential to function as antidotes for intoxication with neurotoxic OPs, suggesting further research on the development of neutral defense agents.
\end{abstract}

Keywords: neutral oximes, huAChE reactivation, paraoxon, chemical warfare, (thiophen-2yl)aldoxime

\section{Introduction}

Intoxication with neurotoxic organophosphorus compounds is a serious problem caused by some pesticides used in agriculture, such as paraoxon (1) and malathion (2) (Figure 1) and chemical warfare agents. ${ }^{1-11}$ According to the World Health Organization, there are about 220,000 intoxications with organophosphorus pesticides throughout the world every year, leading to approximately 20,000 deaths. ${ }^{1,12-14}$ The most dangerous neurotoxic compounds are

*e-mail: figueroa@ime.eb.br the chemical warfare agents soman (3), sarin (4), tabun (5) and VX (6) (Figure 1). Though their use is prohibited by the United Nations, these agents have been employed as weapons by terrorist groups and by countries that did not sign the Chemical Weapon Convention administered by the Organization for the Prohibition of Chemical Weapons (OPCW).

The principal target for the action of neurotoxic organophosphorus compounds is the enzyme acetylcholinesterase $(\mathrm{AChE})$, a serine hydrolase that controls the nerve impulses at the cholinergic receptors in the central and peripheral nervous systems. ${ }^{1,15-20}$ As shown in 
<smiles>CCOP(=O)(OCC)Oc1ccc([N+](=O)[O-])cc1</smiles><smiles>CC(C)OP(C)(=O)F</smiles>

4<smiles>CCOC(=O)CC(OP(=S)(OC)OC)C(=O)OC</smiles>

2<smiles>CC(OP(C)(=O)F)C(C)(C)C</smiles>

3<smiles>COP(C)(=O)c1ccccc1</smiles>

Figure 1. Neurotoxic organophosphorus compounds.

Figure 2, the function of $\mathrm{AChE}(7)$ is the hydrolysis of the nerve impulse transmitter acetylcholine $(\mathbf{8})$. In the AChE active site, a serine residue is responsible for the extraction of the acetyl group of acetylcholine, forming choline (9). If an organophosphorus compound (10) is present, phosphorylation of the serine of AChE may occur, thereby forming the inhibited enzyme (11). This may suffer the loss of an $\mathrm{R}^{+}$group (referred to as the aging process), leading to an irreversible form of the inhibited enzyme (12). The aging process occurs at different times, depending on the nature of the organophosphorus compound. ${ }^{1,21-25}$

An understanding of the processes and mechanisms behind the reactivation of the inhibited $\mathrm{AChE}(\mathbf{1 1})$ is required to develop new drugs for the treatment of intoxication with neurotoxic organophosphorus agents. ${ }^{10}$ The most effective reported reactivation compounds are cationic oximes prepared from pyridine aldehydes. As shown in Figure 3, 1,26-41 when they are converted to their conjugated bases, oximes are believed to function as nucleophiles. In this example, pralidoxime (2-PAM, 13) is converted to the anionic form (14), which makes a nucleophilic attack on the phosphate group, forming the phosphorylated oxime (15) and releasing the activity of AChE.

There are several reports of new oximes that perform better AChE reactivating activity than 2-PAM. ${ }^{34-39}$ The problem with the performance of oximes as reactivators of AChE is that, so far, none of them possess an effective reactivating performance independent of the nature of the intoxicating organophosphorus compound. For this reason, it is desirable to develop new compounds capable of dephosphorylation of inhibited AChE. Several potential AChE reactivating oximes have been proposed, ${ }^{27-30,34-39}$ as well as other types of nucleophiles. ${ }^{40} \mathrm{~A}$ second important point is that the defense agents should be able to act in the brain, making necessary their permeation of the hematoencephalic barrier. Unfortunately, ionic compounds, like the cationic oximes, normally can not permeate the hematoencephalic barrier. One example of an oxime with capacity for hematoencephalic barrier permeation is pro-2-PAM, ${ }^{42}$ a neutral compound that is converted to 2-PAM by oxidation after permeation, ${ }^{43}$ but possesses poor AChE reaction activity. ${ }^{44}$ On the other hand, neutral compounds with a polar surface area (PSA) lower that $60 \AA^{2}$ and molecular mass below 450 Da have better permeation possibility. ${ }^{45-47}$

Another enzyme similar to AChE is butyrylcholinesterase (BChE), which displays about $65 \%$ of amino acid sequence similarity with $\mathrm{AChE} .{ }^{48}$ However, while AChE is involved in the control of nerve pulse transition by hydrolysis of acetylcholine in cholinergic synapses, BChE performs
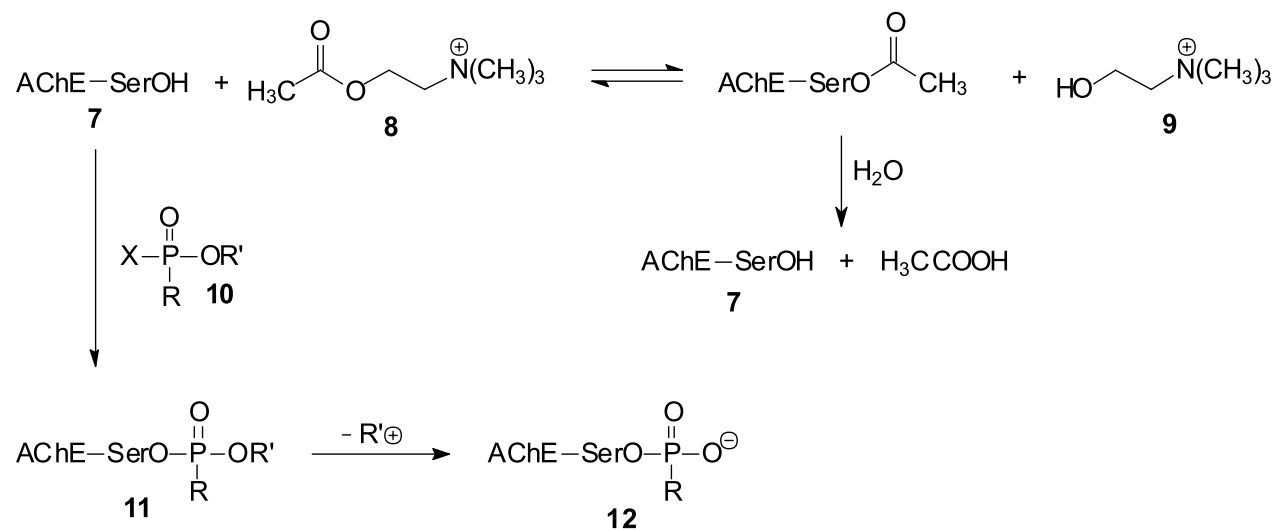

Figure 2. Hydrolysis of acetylcholine by AChE and phosphorylation of AChE. 

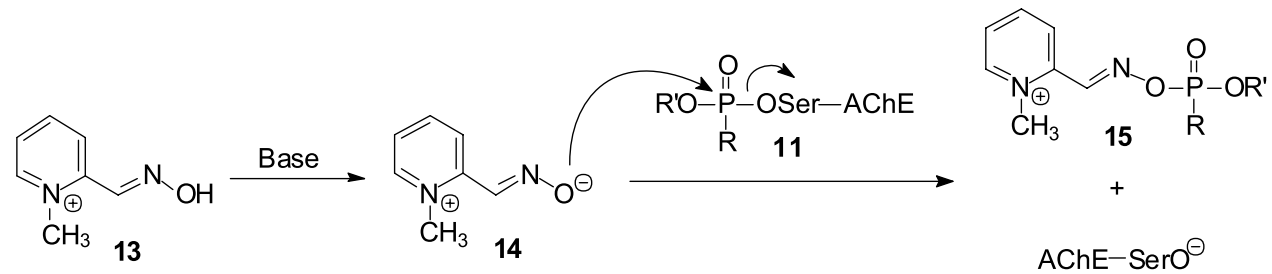

Figure 3. Reactivation of phosphorylated AChE by the action of 2-PAM.

actions in pharmacological and toxicological processes by hydrolysis of drugs containing ester groups and some AChE inhibitors. ${ }^{49,50}$ It is also important to mention that while $\mathrm{AChE}$ is abundant in the brain, erythrocyte membranes and muscles, which are the tissues from it is usually extracted, $\mathrm{BChE}$ is active in the liver, heart, kidneys, intestines and lungs. ${ }^{51}$

In our previous work, the molecular dynamic simulation of the access of oximes to the active site of AChE inhibited with tabun confirmed that the cationic oxime 2-PAM reaches the active site easily, while its anionic form is rejected. ${ }^{41}$ Clearly, the anionic form of 2-PAM is formed inside the AChE active site. In that work, it was also shown that a neutral oxime analogue to 2-PAM, deazapralidoxime or 2-methylphenylaldoxime (16) can effectively access the active site of AChE, indicating that neutral oximes could function as inhibitors of $\mathrm{AChE}$ or potential reactivators of AChE inhibited by organophosphorus compounds, with potential to act in the human brain.

Because non-ionic compounds better penetrate the hematoencephalic barrier, this work explores twelve simple neutral oximes and evaluates their capacity to reactivate human AChE inhibited with paraoxon (1) using the Ellman in vitro test. ${ }^{52}$ The results confirm that neutral oximes can act as AChE reactivators.

\section{Experimental}

\section{Reagents and solvents}

All the reagents (2-methylbenzaldehyde, 3-nitrosalicylaldehyde, 5-nitrosalicylaldehyde, 3-aminobenzaldehyde, 4- $N, N$-dimethylaminobenzaldehyde, 4-methoxybenzaldehyde, pyridine-2-carboxaldehyde, furfuryl-2-carboxaldehyde, thiophene-2-carboxaldehyde, pyrrol-2-carboxaldehyde, $N$-methyl-2-imidazolealdehyde, 4-methyl-5-imidazolecarboxialdehyde, hydroxylamine, (5,5'-dithiobis(2-nitro-benzic acid) (DTNB), acetylthiocholine iodide and ethyl paraoxon) were bought from Sigma-Aldrich and used as received. All solvents bought from Merck, were previously distilled using standard procedures.

\section{Equipments}

IR spectra were obtained from a Perkin-Elmer 457 grating FT spectrometer using $\mathrm{KBr}$ pellets prepared using $1.0 \mathrm{mg}$ of the sample in $100 \mathrm{mg}$ of anhydrous $\mathrm{KBr}$. The ${ }^{1} \mathrm{H}$ and ${ }^{13} \mathrm{C}$ NMR spectra were recorded on a Varian Unity 300 NMR spectrometer using $\mathrm{CDCl}_{3}$ or DMSO- $d_{6}$ as the solvent in sample tubes of $5 \mathrm{~mm}$ diameter, with TMS as the internal reference for the chemical shifts. The sample temperature was controlled using the variable temperature (VT) system of the spectrometer, with an accuracy of $\pm 0.1^{\circ} \mathrm{C}$. The UV-Vis spectra and analyses were obtained using a diode array spectrophotometer from Hewlett-Packard Co. (Mod. 8451A). The refrigerated centrifugation was carried out using a Hitachi Co. centrifuge (Model Himac $\mathrm{CR}_{21} \mathrm{E}$ ).

\section{General synthesis procedures for oximes}

\section{Reactions at room temperature}

In a $50 \mathrm{~mL}$ round bottom flask, $0.226 \mathrm{~g}(4.0 \mathrm{mmol})$ of hydroxylamine hydrochloride was dissolved in a mixture of $10 \mathrm{~mL}$ of ethanol and $3 \mathrm{~mL}$ of distilled water, after which $2.0 \mathrm{mmol}$ of the respective aldehyde were added. The reaction medium was stirred at room temperature for $24 \mathrm{~h}$ and monitored by thin layer chromatography. When the aldehyde was consumed, the solid product was filtered under vacuum, washed with distilled water and dried. The purification was carried out by recrystallization using ethanol, methanol or water, and the products were dried with an infrared lamp for $12 \mathrm{~h}$. The yields varied from 70 to $80 \%$.

\section{Reactions using microwave heating}

In a $100 \mathrm{~mL}$ flask, $0.226 \mathrm{~g}(4.0 \mathrm{mmol})$ of hydroxylamine hydrochloride was dissolved in a mixture of $20 \mathrm{~mL}$ ethanol and $6 \mathrm{~mL}$ of distilled water. Then, $2 \mathrm{mmol}$ of the respective aldehyde were added. The reaction mixture was maintained for $10 \mathrm{~min}$ in a microwave reactor at $160 \mathrm{~W}$, with a frequency of $2450 \mathrm{MHz}$, fitted with a condenser and a thermostat bath. The reaction was monitored by thin layer chromatography. When the aldehyde was completely consumed, the reaction mixture was cooled to room temperature, and the solid product was separated by vacuum filtration, washed with distilled water and dried. 
The products were recrystallized with ethanol, methanol or water. The products were dried under an infrared lamp for $12 \mathrm{~h}$. The yields varied from 80 to $90 \%$.

\section{2-Methylbenzaldehyde oxime (16)}

It was prepared using $0.23 \mathrm{~mL}$ ( $2 \mathrm{mmol}$ ) of 2-methylbenzaldehyde. After recrystallization with methanol, $0.202 \mathrm{~g}$ (75\%) and $0.243 \mathrm{~g} \mathrm{(90 \% )} \mathrm{of} \mathrm{the} \mathrm{oxime} \mathrm{were} \mathrm{obtained} \mathrm{as} \mathrm{white}$ crystals, with conventional and microwave heating, respectively; mp 51-53 ${ }^{\circ} \mathrm{C}$ (Lit. $\left.52-54{ }^{\circ} \mathrm{C}\right) .{ }^{53} \mathrm{NMR}$ and UV spectra data are displayed in the Supplementary Information section.

\section{3-Nitrosalicylaldehyde oxime (17)}

It was prepared using $0.334 \mathrm{~g}(2 \mathrm{mmol})$ of 3-nitrosalicylaldehyde. After recrystallization with ethanol, $0.234 \mathrm{~g}(70 \%)$ and $0.267 \mathrm{~g}(80 \%)$ of the oxime were obtained as yellow solids, with conventional and microwave heating, respectively; mp 207-209 ${ }^{\circ} \mathrm{C} .{ }^{1} \mathrm{H}$ NMR (ppm, DMSO- $\left.d_{6}\right) \delta 11.84(\mathrm{~s}, 2 \mathrm{H}), 8.44(\mathrm{~s}, 1 \mathrm{H}), 7.94(\mathrm{dd}, 1 \mathrm{H}$, $\left.{ }^{3} J 8.2 \mathrm{~Hz},{ }^{4} J 1.5 \mathrm{~Hz},\right), 7.84\left(\mathrm{dd}, 1 \mathrm{H},{ }^{3} J 7.8 \mathrm{~Hz},{ }^{4} J 1.5 \mathrm{~Hz}\right.$,), $7.07(\mathrm{t}, 1 \mathrm{H}) .{ }^{13} \mathrm{C}$ NMR (ppm, DMSO- $\left.d_{6}\right) \delta 150.3,146.7$, 137.2, 133.6, 125.8, 122.0, 119.5. IR (KBr) $v_{\max } / \mathrm{cm}^{-1}$ 3409, 3087-3004, 1631, 1584-1531-1434, 1343, 863. CHN $\left(\mathrm{C}_{7} \mathrm{H}_{6} \mathrm{~N}_{2} \mathrm{O}_{4}\right)$ : calc. $\mathrm{C}(46.2 \%), \mathrm{H}(3.3 \%), \mathrm{N}(15.4 \%)$; found $\mathrm{C}(44.9 \%), \mathrm{H}(3.0 \%), \mathrm{N}(14.8 \%)$.

\section{5-Nitrosalicylaldehyde oxime (18)}

It was prepared using $0.240 \mathrm{~g}(2 \mathrm{mmol})$ of 5 -nitrosalicylaldehyde. After recrystallization with ethanol, $0.240 \mathrm{~g}$ (72\%) and $0.267 \mathrm{~g}(80 \%)$ of the oxime were obtained as yellow solids with conventional and microwave heating, respectively; mp $230-232{ }^{\circ} \mathrm{C} .{ }^{1} \mathrm{H}$ NMR (ppm, DMSO- $\left.d_{6}\right) \delta 11.66(\mathrm{~s}, 2 \mathrm{H}$ ), $8.40\left(\mathrm{~d}, 1 \mathrm{H},{ }^{4} \mathrm{~J} 3.0 \mathrm{~Hz}\right.$ ), $8.34(\mathrm{~s}, 1 \mathrm{H}), 8.10\left(\mathrm{dd}, 1 \mathrm{H},{ }^{3} \mathrm{~J} 9.1 \mathrm{~Hz}\right.$, $\left.{ }^{4} \mathrm{~J} 3.0 \mathrm{~Hz},\right), 7.05\left(\mathrm{~d}, 1 \mathrm{H},{ }^{3} \mathrm{~J} 9.1 \mathrm{~Hz},\right) .{ }^{13} \mathrm{C} \mathrm{NMR}\left(\mathrm{ppm}\right.$, DMSO-d $\left.{ }_{6}\right)$ $\delta$ 161.3, 144.3, 139.9, 126.0, 122.5, 119.4, 116.6. IR (KBr) $v_{\text {max }} / \mathrm{cm}^{-1} 3308,3099-3068,1621,1576-1519-1483,1339,839$. CHN $\left(\mathrm{C}_{7} \mathrm{H}_{6} \mathrm{~N}_{2} \mathrm{O}_{4}\right)$ : calc. C (46.2\%), H (3.3\%), N (15.4\%); found $\mathrm{C}(45.3 \%), \mathrm{H}(3.4 \%), \mathrm{N}(14.9 \%)$.

\section{3-Aminobenzaldehyde oxime (19)}

It was prepared using $0.298 \mathrm{~g}(2 \mathrm{mmol})$ of 3-aminobenzaldehyde. After recrystallization with ethanol, $0.190 \mathrm{~g}$ (70\%) and $0.217 \mathrm{~g}(80 \%)$ of the oxime were obtained as white crystals with conventional and microwave heating, respectively; mp $142-145^{\circ} \mathrm{C} .{ }^{1} \mathrm{H}$ NMR (ppm, $\mathrm{CDCl}_{3}$ ) $\delta 8.09$ (s, 1H), $7.41\left(\mathrm{~d}, 1 \mathrm{H},{ }^{3} J 8.1 \mathrm{~Hz},\right), 7.18(\mathrm{t}, 1 \mathrm{H}), 6.81(\mathrm{~d}, 1 \mathrm{H}$, ${ }^{3} J 7.7 \mathrm{~Hz}$ ), 6.32 (s, 1H). ${ }^{13} \mathrm{C}$ NMR (ppm, $\left.\mathrm{CDCl}_{3}\right) \delta 151.5$, 150.5, 133.4, 132.8, 128.2, 119.7, 111.9. IR $(\mathrm{KBr}) v_{\max } / \mathrm{cm}^{-1}$ 3307, 3006, 2966-2937, 2838, 1608, 1574-1458, 1252, 963. $\mathrm{CHN}\left(\mathrm{C}_{7} \mathrm{H}_{8} \mathrm{~N}_{2} \mathrm{O}\right)$ : calc. C (61.7\%), H (5.9\%), N (20.6\%); found $\mathrm{C}(59.8 \%), \mathrm{H}(5.6 \%), \mathrm{N}(19.6 \%)$.

\section{4- $N, N$-Dimethylaminobenzaldehyde oxime (20)}

It was prepared using $0.298 \mathrm{~g}$ ( $2 \mathrm{mmol})$ of $N, N$ dimethyl- $p$-amino-benzaldehyde. After recrystallization with methanol, $0.229 \mathrm{~g}(70 \%)$ and $0.262 \mathrm{~g}(80 \%)$ of the oxime were obtained as white crystals with conventional and microwave heating, respectively; $\mathrm{mp} 151-153{ }^{\circ} \mathrm{C}$ (Lit. $152-154^{\circ} \mathrm{C}$ ).$^{54} \mathrm{NMR}$ and UV spectra data are displayed in the Supplementary Information section.

\section{4-Methoxybenzaldehyde oxime (21)}

It was prepared using $0.24 \mathrm{~mL}$ ( $2 \mathrm{mmol}$ ) of 4-methoxybenzaldehyde. After recrystallization with methanol, $0.211 \mathrm{~g}(70 \%)$ and $0.242 \mathrm{~g}(80 \%)$ of the oxime were obtained as white crystals with conventional and microwave heating, respectively; mp $131-133{ }^{\circ} \mathrm{C}$ (Lit. $131-133{ }^{\circ} \mathrm{C}$ ).$^{55} \mathrm{NMR}$ and UV spectra data are displayed in the Supplementary Information section.

\section{Pyridine-2-carboxylaldehyde oxime (22)}

It was prepared using $0.19 \mathrm{~mL}$ ( $2 \mathrm{mmol})$ of pyridine2-carboxyaldehyde. After recrystallization with ethanol, $0.183 \mathrm{~g}(75 \%)$ and $0.207 \mathrm{~g}(85 \%)$ of the oxime were obtained as white crystals with conventional and microwave heating, respectively; $\mathrm{mp} 110-112^{\circ} \mathrm{C}\left(\right.$ Lit. $\left.112.5-113^{\circ} \mathrm{C}\right) .^{56}$ NMR and UV spectra data are displayed in Supplementary Information section.

\section{Furane-2-carboxyaldehyde oxime (23)}

It was prepared using $0.16 \mathrm{~mL}(2 \mathrm{mmol})$ of furane2-carboxyaldehyde. After recrystallization with methanol, $0.173 \mathrm{~g}(78 \%)$ and $0.197 \mathrm{~g}(89 \%)$ of the oxime were obtained as amber crystals with conventional and microwave heating, respectively; mp $71-73{ }^{\circ} \mathrm{C}$ (Lit. $\left.70-72{ }^{\circ} \mathrm{C}\right) .{ }^{57} \mathrm{NMR}$ and UV spectra data are displayed in the Supplementary Information section.

Thiophene-2-carboxylaldehyde oxime or (thiophen-2-yl) aldoxime (24)

It was prepared using $0.18 \mathrm{~mL}(2.0 \mathrm{mmol})$ of thiophene-2-carboxyaldehyde. After recrystallization with distilled water, $0.203 \mathrm{~g}(80 \%)$ and $0.228 \mathrm{~g}(90 \%)$ of the oxime were obtained as white solids with conventional and microwave heating, respectively; mp $135-137{ }^{\circ} \mathrm{C}$ (Lit. $135-136{ }^{\circ} \mathrm{C}$ ).$^{58} \mathrm{NMR}$ and UV spectra data are displayed in the Supplementary Information section.

\section{Pyrrol-2-carboxyaldehyde oxime (25)}

It was prepared using $0.190 \mathrm{~g}(2 \mathrm{mmol})$ of pyrrol2-carboxaldehyde. After recrystallization with ethanol, $0.176 \mathrm{~g}(80 \%)$ and $0.198 \mathrm{~g}(90 \%)$ of the oxime were obtained as beige solids with conventional and microwave heating, 
respectively; mp $183-185{ }^{\circ} \mathrm{C}$ (Lit. $182-184{ }^{\circ} \mathrm{C}$ )..$^{59} \mathrm{NMR}$ and UV spectra data are displayed in the Supplementary Information section.

\section{1-Methylimidazole-2-carboxyaldehyde oxime (26)}

It was prepared using $0.220 \mathrm{~g}$ ( $2 \mathrm{mmol})$ of 1-methylimidazole-2-carboxyaldehyde. After recrystallization with ethanol, $0.212 \mathrm{~g}(85 \%)$ and $0.225 \mathrm{~g}(90 \%)$ of the oxime were obtained as beige solids with conventional and microwave heating, respectively; mp $169-171{ }^{\circ} \mathrm{C}$ (Lit. 168-169 ${ }^{\circ} \mathrm{C}$ ). ${ }^{60} \mathrm{NMR}$ and UV spectra data are displayed in the Supplementary Information section.

\section{4-Methylimidazole-5-carboxyaldehyde oxime (27)}

It was prepared using $0.220 \mathrm{~g}$ ( $2 \mathrm{mmol})$ of 4-methylimidazole-5-carboxyaldehyde. After recrystallization with ethanol, $0.212 \mathrm{~g}(85 \%)$ and $0.225 \mathrm{~g}(90 \%)$ of the oxime were obtained as beige solids with conventional and microwave heating, respectively; mp 170-172 ${ }^{\circ} \mathrm{C} .{ }^{1} \mathrm{H}$ NMR $\left(\mathrm{ppm}, \mathrm{DMSO}-d_{6}\right) \delta 8.38(\mathrm{~s}, 1 \mathrm{H}), 8.18(\mathrm{~s}, 1 \mathrm{H}), 2.55(\mathrm{~s}$, $3 \mathrm{H}) .{ }^{13} \mathrm{C}$ NMR (ppm, DMSO- $\left.d_{6}\right) \delta 146.8,139.4,135.8$, 127.3, 11.7. IR (KBr) $v_{\max } / \mathrm{cm}^{-1} 3407,3131,3044,2926$, 2872, 1655, 1609, 1490, 1434, 1327. CHN $\left(\mathrm{C}_{5} \mathrm{H}_{7} \mathrm{~N}_{3} \mathrm{O}\right)$ : calc. C (48.0\%), H (5.6\%), N (33,6\%); found C (46.4\%), $\mathrm{H}(5.2 \%), \mathrm{N}(31.9 \%)$.

\section{Blood samples}

Venous blood samples $(10 \mathrm{~mL})$ were obtained by venipuncture from volunteers not exposed to organophosphorus pesticides. All the collected blood samples were mixed and homogenized by gentle hand shaking. To obtain the active AChE, $1.8 \mathrm{~mL}$ blood samples were mixed with $200 \mu \mathrm{L}$ of phosphate buffer $\left(120 \mathrm{mmol} \mathrm{L}^{-1}\right.$, $\mathrm{pH}$ 7.6) to a final volume of $2 \mathrm{~mL}$. To obtain the paraoxon inhibited AChE blood samples, $1.8 \mathrm{~mL}$ of blood were first incubated with $20 \mu \mathrm{L}$ of ethyl paraoxon $\left(0.125 \mathrm{mg} \mathrm{mL}^{-1}\right)$ at room temperature for $15 \mathrm{~min}$. A $2 \mathrm{~mL}$ final volume of the paraoxon inhibited AChE blood sample was obtained by the addition of $180 \mu \mathrm{L}$ of phosphate buffer. For all cases, the homogenized samples were centrifuged for $10 \mathrm{~min}$ to separate the plasma from the cells. Aliquots of $500 \mu \mathrm{L}$ of the cells were suspended in $4.5 \mathrm{~mL}$ of lysis buffer (sodium phosphate $20 \mathrm{mmol} \mathrm{L}^{-1}, \mathrm{pH} 7.6$ ) and frozen for $24 \mathrm{~h}$. Then, the cell samples were thawed and centrifuged (4000 g) under refrigeration $\left(5-8{ }^{\circ} \mathrm{C}\right)$. The supernatant was poured off, and the precipitate was suspended in $4.5 \mathrm{~mL}$ of the initial buffer. This procedure was repeated three times. The final residue was suspended in $500 \mu \mathrm{L}$ of analysis buffer (sodium phosphate $120 \mathrm{mmol} \mathrm{L}^{-1}, \mathrm{pH}$ 7.6), and called the ghost. The AchE activities were determined in the ghost fractions. The stabilities of the enzymatic activities were tested by freezing the ghost samples for 28 days and evaluating their activities after melting the samples. All buffer solutions were stable for more than 3 months when refrigerated. The acetylthiocholine solutions $\left(6.6 \mathrm{mmol} \mathrm{L}^{-1}\right)$, which were prepared in water, were stable for 2 weeks when frozen $\left(-20^{\circ} \mathrm{C}\right)$.

\section{AChE activity measurement}

Each ghost sample activity was kinetically determined as follows. An aliquot of $50 \mu \mathrm{L}$ of ghost sample was incubated at $25{ }^{\circ} \mathrm{C}$ for $1 \mathrm{~min}$ with $4 \mathrm{~mL}$ of buffer (sodium phosphate $120 \mathrm{mmol} \mathrm{L}^{-1}, \mathrm{pH}$ 7.6) and $1 \mathrm{~mL}$ of a $2 \mathrm{mmol} \mathrm{L}^{-1}$ solution of dithio-nitrobenzene (DTNB) prepared in the same buffer. The reaction was initiated by adding $1 \mathrm{~mL}$ of acetylthiocholine iodide $\left(6.6 \mathrm{mmol} \mathrm{L}^{-1}\right.$ in distilled or deionized water) to the incubated mixtures. The absorbance of this mixture was measured at $412 \mathrm{~nm}$, immediately after addition of the acetylthiocholine and used as a blank. Further absorbances were measured at 30, 60, 90 and $120 \mathrm{~s}$ after the addition of acetylthiocholine, and the average absorbance variation per min was used to calculate the enzymatic activity.

The analyses were performed at room temperature. The cholinesterase activities were calculated using standard curves of L-cysteine, according to the equation below,

$\mathrm{E}=\left[\frac{\left(\mathrm{Abs} \mathrm{min}^{-1} \times 10^{-3}\right)-2.96}{2.11}\right] \times 20$

where $\mathrm{E}$ is the enzyme activity in nmols $\mathrm{min}^{-1} \mathrm{~mL}^{-1}$, Abs is the absorbance, 2.96 and 2.11 are the linear coefficient and the slope of the curve, respectively, experimentally obtained for L-cysteine, and 20 is the dilution factor. ${ }^{52}$

\section{Protein concentration}

The AChE concentration was determined for each ghost sample by adding $50 \mu \mathrm{L}$ of the ghost sample to $4.45 \mathrm{~mL}$ of deionized water with $200 \mu \mathrm{L}$ of $20 \% \mathrm{~m} / \mathrm{v} \mathrm{NaOH}$ and $300 \mu \mathrm{L}$ of Folling reagent (used pure from SigmaAldrich Co) and by comparing this solution to the standard albumin solutions $(1 \mathrm{mg} \mathrm{mL}-1)$ prepared as described in Table 1. In all cases, after mixing for $5 \mathrm{~min}$, the absorbance was determined at $660 \mathrm{~nm}$.

The standard curve for albumin was obtained from the absorbance measurements of standards 100 and 300, and graphs of the absorbance values of the ghost samples were made to determine their concentration of $\mathrm{AChE}$ in $\mathrm{mg} \mathrm{mL}^{-1}$. To calculate the $\mathrm{AChE}$ specific activity $\left(\mathrm{E}_{\mathrm{a}}\right)$, the values of 
Table 1. Albumin solutions for absorbance comparison with ghost samples for the determination of the concentration of $\mathrm{AChE}$

\begin{tabular}{lcc}
\hline Solution name & $\mathrm{H}_{2} \mathrm{O} / \mathrm{mL}$ & $\begin{array}{c}\text { Albumin solution } \\
\text { volume } / \mu \mathrm{L}\end{array}$ \\
\hline White & 4.50 & 0 \\
Standard 100 & 4.45 & 50 \\
Standard 200 & 4.40 & 100 \\
Standard 300 & 4.20 & 300 \\
Ghost samples & 4.45 & 50 \\
\hline
\end{tabular}

the AChE activity (E) were divided by the concentration of protein (P) and expressed in $\mu \mathrm{mol} \mathrm{min} \mathrm{mg}^{-1} \mathrm{mg}^{-1}$ oChE.

\section{Reactivation of huAChE inhibited with paraoxon}

Aliquots of $192 \mu \mathrm{L}$ of each ghost sample obtained from blood samples contaminated with paraoxon were used to determine each oxime capacity to reactivate $\mathrm{AChE}$ inhibited with paraoxon. This volume of each ghost sample was mixed with $32 \mu \mathrm{L}$ of the assay buffer (sodium phosphate $120 \mathrm{mmol} \mathrm{L}^{-1}, \mathrm{pH}$ 7.6) and $16 \mu \mathrm{L}$ of the respective oxime at a concentration of $25 \mathrm{mmol} \mathrm{L}^{-1}$ and $1 \mathrm{~mL}$ of a $2 \mathrm{mmol} \mathrm{L}^{-1}$ solution of dithio-nitrobenzene (DTNB), both diluted in the same buffer (sodium phosphate $120 \mathrm{mmol} \mathrm{L}^{-1}, \mathrm{pH}$ 7.6). After $30 \mathrm{~min}$, the reaction was initiated by adding $1 \mathrm{~mL}$ of acetylthiocholine iodide $\left(6.6 \mathrm{mmol} \mathrm{L}^{-1}\right.$ in distilled or deionized water) to the incubated mixtures. The activity determination was performed by monitoring the UV-Vis absorbance at a $\lambda 412 \mathrm{~nm}$ using the methodology previously described. All the tests were performed in triplicate.

\section{Results and Discussion}

The oximes were prepared using two methodologies: (i) the reaction of aldehydes with hydroxylamine hydrochloride at room temperature for $24 \mathrm{~h}$ and (ii) the reaction using microwave irradiation for $10 \mathrm{~min}$. Both procedures lead to oxime yields of 70 to $90 \%$, but the microwave irradiation method lead to shorter reaction times (10 min) and greater yields (80 to 90\%, Figure 4).
The reactions had relative yields greater than $70 \%$, and all the oximes were obtained as $E$-isomers, as determined by analysis of the ${ }^{1} \mathrm{H}$ NMR spectra of the reaction mixtures (in the Supplementary Information section). As the mixtures were not separated, all the compounds were tested as the $Z / E$ mixtures, but with more than $95 \%$ of $E$-isomers.

The Ellman tests were conducted using human blood from volunteers who have low possibilities of being intoxicated with organophosphorus compounds..$^{52}$ To obtain the active AchE, the erythrocytes were separated by centrifugation of a $1.8 \mathrm{~mL}$ blood sample, ruptured by freezing the cells in phosphate buffer $\left(20 \mathrm{mmol} \mathrm{L}^{-1}\right.$, $\mathrm{pH}$ 7.6) at $-10{ }^{\circ} \mathrm{C}$ and then centrifuged to separate the hemoglobin. Finally, the membranes were treated with a lyophilizing phosphate buffer and subsequently centrifuged to yield $500 \mu \mathrm{L}$ of clean AChE solution. The hydrolytic activity of the enzyme was confirmed with the Ellman test using acetylthiocholine as a substrate in the presence of dithionitrobenzoic acid. The same procedure was employed with other fractions of the blood samples that were previously treated with a paraoxon at a $3.64 \mu \mathrm{mol} \mathrm{L}^{-1}$ concentration for $15 \mathrm{~min}$ at room temperature, leading to $100 \%$ inhibition of AChE, as confirmed with the Ellman test. The capacities of the oximes to reactivate the inhibited $\mathrm{AChE}$ were determined by repeating the Ellman test in the presence of different concentrations of the oximes. All the tests were repeated three times. The results for the reactivation tests using a $1.8 \mathrm{mmol} \mathrm{L}^{-1}$ concentration of each oxime in $224 \mu \mathrm{L}$ of the solution of inhibited AChE are shown in Table 2. Today, there are several oximes with very good AChE reactivation capacity, but in this work, pralidoxime (13) was used as the positive test due to its structural similarity to the tested neutral oximes in order to determine the effect of is cationic nature.

Since all the oximes were tested as reactivators at the same concentration $\left(16 \mu \mathrm{L}\right.$ of $25 \mathrm{mmol} \mathrm{L}^{-1}$ solution of each oxime), Table 2 shows that the neutral oximes have the capacity to reactivate huAChE inhibited with paraoxon, with (thiophen-2-yl)aldoxime (24) displaying a better performance (93\%) than 2-PAM (83\%). It is interesting

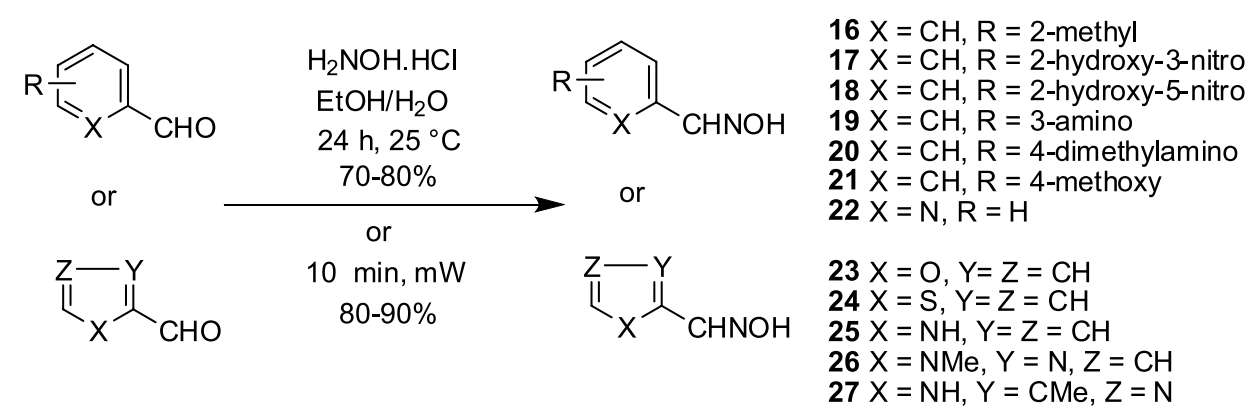

Figure 4. Synthesis of the oximes. 
Table 2. Results of oximes reactivation capacity of AChE inhibited with ethyl paraoxon and comparison with the pKa values and the calculated energy difference $(\Delta \mathrm{E})$ between the neutral and the deprotonated form of each oxime

\begin{tabular}{|c|c|c|c|c|c|c|c|}
\hline Oxime & $\begin{array}{c}\mathrm{AChE} \\
\text { reactivation }{ }^{\mathrm{a}} / \\
(\%, \pm 1)\end{array}$ & $\mathrm{pKa}$ & $\Delta \mathrm{E} / \mathrm{au}$ & Oxime & $\begin{array}{c}\mathrm{AChE} \\
\text { reactivation }^{\mathrm{a}} / \\
(\%, \pm 1)\end{array}$ & $\mathrm{pKa}$ & $\Delta \mathrm{E} / \mathrm{au}$ \\
\hline 13 & 83 & 7.68 & -0.406 & 22 & 22 & 10.00 & -0.567 \\
\hline 16 & 18 & 11.47 & -0.571 & 23 & 38 & 10.56 & -0.457 \\
\hline 17 & 62 & 11.39 & -0.537 & 24 & 93 & 10.63 & -0.560 \\
\hline 18 & 58 & 11.39 & -0.535 & 25 & 21 & 17.69 & -0.568 \\
\hline 19 & 38 & 11.60 & -0.465 & 26 & 40 & 10.54 & -0.561 \\
\hline 20 & 16 & 11.87 & -0.582 & 27 & 19 & 15.32 & -0.450 \\
\hline 21 & 14 & 11.49 & -0.575 & & & & \\
\hline
\end{tabular}

${ }^{\mathrm{a}}$ All the oximes were tested with the same concentration $(0.167 \mu \mathrm{mol} \mathrm{L}-1)$.

that the nitrated oximes $\mathbf{1 7}$ and $\mathbf{1 8}$ are also effective, with a reactivation capacity of 62 and 58\%, respectively. This indicates that electron withdrawing groups could increase the reactivation capacity of the aromatic oximes. A medium reactivation capacity (38 to $40 \%$ ) was obtained with the oximes of 2-furfuraldehyde (23), 3-aminobenzaldehyde (19) and 1-methyl-2-imidazolaldehyde (26). In contrast, aromatic oximes with electron donating groups at para or ortho positions lead to the lowest reactivation capacities (oximes of 4-methoxybenzaldehyde (21, 14\%), 4-dimethylaminobenzaldehyde $(\mathbf{2 0}, 16 \%)$ and 2-methylbenzaldehyde (16, 18\%)). These results indicate that the presence of electron donating groups in conjugation with the oxime $\mathrm{C}=\mathrm{N}$ bond, which is not the case for the oxime of 3-aminobenzaldehyde $(\mathbf{1 9}, 38 \%)$, leads to lower reactivation capacities possibly due to the induced decrease of the acidity of the oxime O-H hydrogen. This observation is supported by the reactivation mechanism shown in Figure 3, where the active form of the oxime at the active site of the phosphilated AChE is the conjugated base.

For the most active oximes, (thiophen-2-yl)aldoxime and 2-PAM, it is clear that the oxime acidity is increased by the electrophilicity of their aromatic rings. For 2-PAM, the positive charge at the nitrogen atom of the pyridine ring leads to a strong stabilization of its conjugate base. In the case of (thiophen-2-yl)aldoxime, the negative charge of the conjugated base is stabilized in the five conjugated forms, including the case where the sulfur atom becomes negative, as shown in Figure 5. Evidently, the (thiophen-2-yl) aldoxime is much less acid than 2-PAM, but it seems that the presence of the sulfur atom due to it potential for polarization helps to stabilize the negative charge of its anionic form.

Similar stabilities should be found for the anionic forms of the nitrated oximes (17 and 18), but these compounds display a lower reactivation activity possibly due to the electrostatic or steric effects of the nitro groups in the AChE active site, as well as the presence of the electron donor hydroxyl group at the ortho position.

To determine if there was a correlation between the acidity of the oximes and their AChE reactivating capacity, energy calculations were completed for the most stable conformer of each oxime in the protonated (neutral) and deprotonated (anionic) forms, and the energy difference between the two forms for each oxime was used as an indicator of its acidity. Alternatively, the oximes acidities could be determined using their pKa values. However, the accuracy of the pKa values reported for oximes has been questioned. ${ }^{61}$

The energy calculations were executed via the Spartan'06 program using B3LYP and the base system 6-311++G(d,p). The results are shown in Table 2.

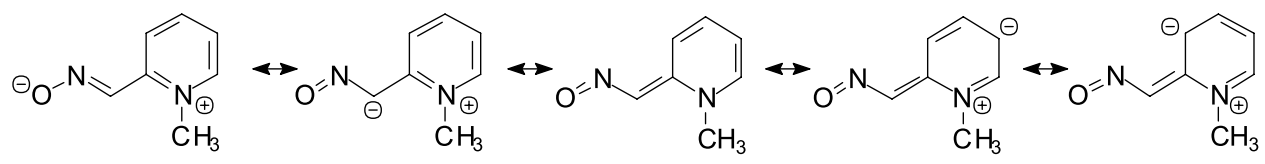

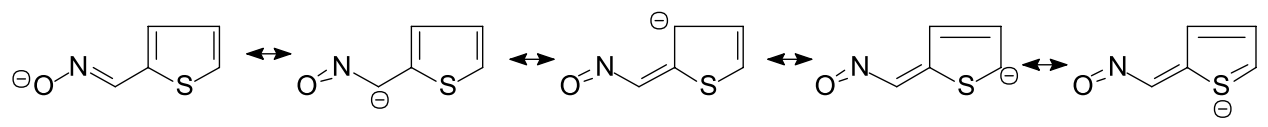

Figure 5. Stabilization resonance of the anionic forms of 2-PAM (13) and (thiophen-2-yl)adoxime (24). 
Interestingly, neither the pKa values nor the calculated $\Delta \mathrm{E}$ values correlate directly with the experimental $\mathrm{AChE}$ reactivation capacity of the oximes. Analysis of the data indicates that electron withdrawing substituents on the aromatic rings of the oximes play an important role in increasing their efficiency as reactivators of $\mathrm{AChE}$ inhibited with paraoxon. However, it is very clear that other factors must be considered in relation to the activity of these compounds. For example, 2-PAM, which is the reference material, is the second most active compound (83\% reactivation) and the most basic oxime (pKa 7.68 and $\Delta \mathrm{E}-0.406 \mathrm{au}$ ), but it is less effective than (thiophen-2-yl) aldoxime (93\% reactivation), which is much less acidic (pKa 10.63) and exhibits lower stability in its anionic form $(\Delta \mathrm{E}-0.560 \mathrm{au})$. Thus, although the less acidic oximes would generate more effective nucleophiles for AChE reactivation, these conjugated bases are more difficult to be generated at the huAChE active site. On the other hand, the more acidic oximes should be easily deprotonated, explaining why 2-PAM is one of the best reactivators of AChE inhibited with paraoxon.

\section{Conclusions}

The penetration of oximes on the hematoencephalic barrier is a very important point for their activity as antidotes against neurotoxic organophosphorus compounds. ${ }^{62}$ This study provides evidence that neutral oximes, which possess better capacities for membrane and hematoencephalic barrier permeation, exhibit potential as reactivators of human acetylcholinesterase inhibited with paraoxon. The comparison of the activities of the different oximes with their acidities (pKa values and $\Delta \mathrm{E}=\mathrm{E}_{\text {protonated }}-\mathrm{E}_{\text {anionic }}$ ) did not reveal a clear direct correlation between these values and the respective $\mathrm{AChE}$ reactivating capacities. The comparison between the $\Delta \mathrm{E}$ values and the reactivating capacity for 2-PAM and oximes 16 to 22 , which have similar structures, displays a $R^{2}$ value of 0.62 , indicating that there is some correlation between $\Delta \mathrm{E}$ and the percentage of reactivation of huAChE. Despite the fact that the oximes acidity seems not directly involved with their AChE reactivation capacity, these results suggest that exists some dependence of oxime activity on its acidity, indicating that there should exist different pathways for oxime deprotonation at the huAChE active site mostly due to their differences in structure and the substitution groups at the aromatic ring. This is evident by the observation that neutral oximes containing electron deficient substituents on their aromatic rings, especially at positions that permit a direct conjugation with the oxime $\mathrm{C}=\mathrm{N}$ bond, are the most effective. In addition to the capacity of an oxime to be deprotonated inside the enzyme active site, it is clear that other important factors are involved in determining the oxime $\mathrm{AChE}$ reactivating capacities. ${ }^{63}$ Future studies are needed to elucidate the nature of these other factors.

It is also necessary to carry out evaluation tests using AChE inhibited with other compounds, like chemical warfare agents to determine the potential of neutral oximes for the general treatment of intoxication with neurotoxic organophosphorus agents.

Another potential point to correlate oxime structures with $\mathrm{AChE}$ reactivation activity is to perform the tests using the pure form of the $E$ and $Z$ isomers. Unfortunately, this topic is difficult because for most oximes when the isomers are separated they rapidly become an $E / Z$ mixture. We have separated some $E$ isomers from oximes by fast chromatography followed by rapid solvent elimination, but when their solutions are prepared for analysis they start to transform in the $E / Z$ mixture, and the speed of transformation depends on the solvent and the oxime structure.

Because neutral oximes can reactivate phosphorylated human AChE, it is also possible that they could lead to the development of new AChE inhibitors, with potential as drugs for Alzheimer disease.

\section{Supplementary Information}

Supplementary data are available free of charge at http://jbcs.sbq.org.br as PDF file.

\section{Acknowledgments}

We are grateful for financial support given by Conselho de Desenvolvimento Científico e Tecnológico (CNPq), Instituto Nacional de Ciência e Tecnologia de Biologia Estrutural e Bioimagem (INBEB), Coordenação de Aperfeiçoamento de Pessoal de Nível Superior (CAPES) and Brazilian Ministry of Defense (CAPES-Pró-defesa).

\section{References}

1. Delfino, R. T.; Ribeiro, T. S.; Figueroa-Villar, J. D.; J. Braz. Chem. Soc. 2009, 20, 407.

2. Sidell, F. R.; Borak, J. J.; Ann. Emerg. Med. 1992, 21, 865.

3. Sidell, F. R. In Medicinal Aspects of Chemical and Biological Warfare; Sidell, F. R.; Takafuji, E. T.; Franz, D. R., eds.; Office of Surgeon General US Army, Borden Institute: Washington, 1997, ch. 5.

4. Benschop, H. P.; De Jong, L. P. A.; Acc. Chem. Res. 1988, 21 , 368. 
5. Black, R. M.; Harrison, J. M. In The Chemistry of Organophosphorus Compounds; Hartley, T.; Frank, R., eds.; John Wiley \& Sons: New York, 1996, ch. 11.

6. Cannard, K.; J. Neurol. Sci. 2006, 249, 86.

7. Carlton, F. B.; Simpson, W. M.; Haddad, L. M. In Clinical Management of Poisoning and Drug Overdose; Haddad, L. M.; Shannon, M. W.; Winchester, J. F., eds.; W. B. Saunders Company: Philadelphia, 1998, ch. 105.

8. Chauhan, S.; Chauhan, S.; D’Cruz, R.; Faruqi, S.; Singh, K. K.; Varma, S.; Singh, M.; Karthik, V.; Environ. Toxicol. Pharmacol. 2008, 26, 113.

9. Marrs, T. C. In Chemical Warfare Agents: Toxicology and Treatment; Marrs T. C.; Maynard, R. L.; Sidell, F. R., eds.; John Wiley \& Sons, Ltd: Wiltshire, 2007, ch. 8.

10. Gonçalves, A. S.; França, T. C. C.; Figueroa-Villar, J. D.; Pascutti, P. G.; J. Braz. Chem. Soc. 2010, 21, 179.

11. Brown, M. A.; Brix, K. A.; J. Appl. Toxicol. 1998, 18, 393.

12. Sogorb, M.A.; Vilanova, E.; Carrera,V.; Toxicol. Lett. 2004, 151,219 .

13. Gunnell, D.; Eddleston, M.; Phillips, M. R.; Konradsen, F.; BMC Public Health 2007, 7, 357.

14. Volans, A. P.; J. Accid. Emerg. Med. 1996, 13, 202.

15. Taylor, P.; Brown, J. H. In Basic Neurochemistry: Molecular, Cellular and Medical Aspects; Siegel, G. J.; Albers, R. W.; Brady, S.; Price, D., eds.; Elsevier Academic Press: San Diego, 2006, ch. 11.

16. Taylor,P.; Radic,Z:;Annu. Rev. Pharmacol. Toxicol. 1994, 34, 281.

17. Massoulié, J.; Pezzementi, L.; Bon, S.; Krejci, E.; Prog. Neurobiol. 1993, 41, 31.

18. Silman, I.; Sussman, J. L.; Curr. Opin. Pharmacol. 2005, 5, 293.

19. Soreq, H.; Seidman, S.; Nat. Rev. Neurosci. 2001, 2, 294.

20. Sussman, J. L.; Harel, M.; Frolow, F.; Oefner, C.; Goldman, A.; Toker, L.; Silman, I., Science 1991, 253, 872.

21. dos Santos, V. M. R.; Donnici, C. L.; da Costa, J. B. N.; Caixeiro, J. M. R.; Quim. Nova 2007, 30, 159.

22. Thiermann, H.; Szinicz, L.; Eyer, P.; Felgenhauer, N.; Zilker, T.; Toxicol. Lett. 1999, 107, 233.

23. Viragh, C.; Akhmetshin, R.; Kovach, I. M.; Biochemistry 1997, 36,8243 .

24. Toy, D. F.; Phosphorus Chemistry in Everyday Living; Americam Chemical Society: Washington, 1976.

25. Worek, F.; Thiermann, H.; Szinicz, L.; Arch. Toxicol. 2004, 78, 212.

26. Ashani, Y.; Radic, Z.; Tsigelny, I.; Vellom, D. C.; Pickering, N. A.; Quinn, D. M.; Doctor, B. P.; Taylor, P.; J. Biol. Chem. 1995, 270,6370 .

27. Vrdoljak, A. L.; Calic, M.; Radic, B.; Berend, S.; Jun, D.; Kuca, K.; Kovarik, Z.; Toxicology 2006, 228, 41.

28. Calic, M.; Vrdoljak, A. L.; Radic, B.; Jelic, D.; Jun, D.; Kuca, K.; Kovarik, Z.; Toxicology 2006, 219, 85.
29. Musilek, K.; Holas, O.; Jun, D.; Dohnal, V.; Gunn-Moore, F.; Opletalova, V.; Dolezal, M.; Kuca, K.; Bioorg. Med. Chem. 2007, 15, 6733.

30. Musilek, K.; Kuca, K.; Jun, D.; Dohnal, V.; Dolezal, M.; Toxicol. Lett. 2005, 158, S134.

31. de Castro, A. T.; Figueroa-Villar, J. D.; Int. J. Quantum Chem. 2002, 89, 135.

32. Silva, G. R.; Júnior, I. B.; Figueroa-Villar, J. D.; Int. J. Quantum Chem. 2005, 105, 260.

33. Gonçalves, A. S.; França, T. C. C.; Figueroa-Villar, J. D.; Pacutti, P. G.; J. Braz. Chem. Soc. 2011, 22, 155.

34. Kuca, K.; Jun, D.; Kim, T. H.; Cabal, J.; Jung, Y. S.; Bull. Korean Chem. Soc. 2006, 27, 395.

35. Kuca, K.; Jun, D.; Cabal, J.; Musilova, L.; Basic Clin. Pharmacol. Toxicol. 2007, 101, 25.

36. Jun, D.; Kuca, K.; Picha, J.; Koleckar, V.; Marek, J.; Drug Chem. Toxicol. 2008, 31, 1.

37. Kuca, K.; Musilova, L.; Palecek, J.; Cirkva, V.; Paar, M.; Musilek, K.; Hrabinova, M.; Pohanka, M.; Karasova, J. Z.; Jun, D.; Molecules 2009, 14, 4915.

38. Jun, D.; Musilova, L.; Miroslav, P.; Jung, Y. S.; Bostik, P.; Kuca, K.; Int. J. Mol. Sci. 2010, 11, 2856.

39. Worek, F.; Thiermann, H.; Szinicz, L.; Eyer, P.; Biochem. Pharmacol. 2004, 68, 2237.

40. Delfino, R. T.; Figueroa-Villar, J. D.; J. Phys. Chem. B 2009, 113,8402 .

41. Gonçalves, A. S.; França, T. C. C.; Wilter, A.; Figueroa-Villar, J. D.; J. Braz. Chem. Soc. 2006, 17, 968.

42. Bodor, N.; Shek, E.; Higuchi, T.; J. Med. Chem. 1976, 19, 102.

43. Khan, F. A.; Campbell, A. J.; Hoyt, B.; Herdman, C.; Ku, T.; Thangavelu, S.; Gordon, R. K.; Life Sci. 2011, 89, 911.

44. Demar, J. C.; Clarkson, E. D.; Ratcliffe, R. H.; Campbell, A. J.; Thangavelu, S. G.; Herdman, C. A.; Leader, H.; Schulz, S. M.; Marek, E.; Medynets, M. A.; Ku, T. C.; Evans, S. A.; Khan, F. A.; Owens, R. R.; Nambiar, M. P.; Gordon, R. K.; Chem. Biol. Interact. 2010, 187, 191.

45. van de Waterbeemd, H.; Camenisch, G.; Folkers, G.; Chretien, J. R.; Raevsky, O. A.; J. Drug Target 1998, 6, 151.

46. Clark, D. E.; Drug Discov. Today 2003, 8, 927.

47. Alavijeh, M. S.; Chishty, M.; Qaiser, M. Z.; Palmer, A. M.; Neurotherapeutics 2005, 2, 554.

48. Cokugras, A. N.; Turk. J. Biochem. 2003, $28,54$.

49. Raveh, L.; Grauver, E.; Grunwald, J.; Cohen, E.; Ashani, Y.; Toxicol. Appl. Pharmacol. 1997, 145, 43.

50. Saxena, A.; Sun, W.; Dabisch, P. A.; Hulet, S. W.; Hastings, N. B.; Jakubowski, E. M.; Mioduszewski, R. J.; Doctor, B. P.; Biochem. Pharmacol. 2011, 82, 1984.

51. Dave, K. R.; Syal, A. R.; Katyare, S. S.; Z. Naturforsch. (C) 2000, 55, 100. 
52. Oliveira-Silva, J. J.; Alves, S. R.; Inacio, A. F.; Meyer, A.; Sarcinelli, P. N.; Mattos, R. C.; Ferreira, M.; Cunha, J. C.; Moreira, J. C.; Hum. Exp. Toxicol. 2000, 19, 173.

53. Kapuriya, N.; Kapuriya, K.; Dodia, N. N.; Lin, Y.W.; Kakadiya, R.; Wu, C. T.; Chen, C. H.; Naliapara, Y.; Su, T. L.; Tetrahedron Lett. 2008, 49, 2886.

54. Li, J. T.; Li, X. L.; Li, T. S.; Ultrason. Sonochem. 2006, 13, 200.

55. Badri, R.; Shushizadeh, M. R.; Phosphorus Sulfur Silicon Relat. Elem. 2007, 182, 601.

56. Poziomek, E. J.; Hackley, B. E.; Steinberg, G. M.; J. Org. Chem. 1958, 23, 714 .

57. Murata, K.; Kiriyama, N.; Domestic Sci. 1946, 17, 195.

58. Grunanger, P.; Finzi, P. V.; Gazz. Chim. Ital. 1959, 89, 1771.
59. Fournari, P.; Tirouflet, J.; Bull. Soc. Chim. Fr. 1963, 484.

60. Phalguni, C.; Weyhermueller, T.; Wagner, R.; Khanra, S.; Biswas, B.; Bothe, E.; Bill, E.; Inorg. Chem. 2007, 46, 9003.

61. Yao, F.; Lei, L.; Yi-Min, W.; Jia-Ning, L.; Tang-Qing, Y.; QingXiang, G.; J. Phys. Chem. A 2006, 110, 5874.

62. Viciu, V. A.; Bajgar, J.; Medvedovici, A.; Radulescu, F. S.; Miron, D. S.; J. Appl. Toxicol. 2010, 30, 719.

63. Aurbek, N.; Herkert, N. M.; Koller, M.; Thiermann, H.; Worek, F.; Chem-Biol. Interact. 2010, 187, 215.

Submitted: February 8, 2012

Published online: June 12, 2012 


\title{
The Effect of Neutral Oximes on the Reactivation of Human Acetylcholinesterase Inhibited with Paraoxon
}

\author{
Tatiana S. Ribeiro, ${ }^{a}$ Arthur Prates, ${ }^{b}$ Sérgio R. Alves, ${ }^{b}$ Jefferson J. Oliveira-Silva, ${ }^{b}$ \\ Carlos A. S. Riehl ${ }^{c}$ and J. Daniel Figueroa-Villar*,a \\ ${ }^{a}$ Departamento de Química, Instituto Militar de Engenharia, Praça General Tibúrcio, 80, \\ Praia Vermelha, 22290-270 Rio de Janeiro-RJ, Brazil
}

${ }^{b}$ Centro de Estudos da Saúde do Trabalhador e Ecologia Humana (CESTEH), ENSP, Fiocruz, Rua Leopoldo Bulhões, 1480, Manguinhos, 21041-210 Rio de Janeiro-RJ, Brazil

'Instituto de Química, Universidade Federal do Rio de Janeiro, Ilha do Fundão, Rio de Janeiro-RJ, Brazil

\section{NMR and IR Data of the Oximes Previously Reported in the Literature}

2-Methylbenzaldehyde oxime (16)

mp 51-53 ${ }^{\circ} \mathrm{C}\left(52-54{ }^{\circ} \mathrm{C}\right) ;{ }^{1} \mathrm{H}$ NMR (ppm, DMSO- $\left.d_{6}\right) \delta$ $11.26(\mathrm{~s}, 1 \mathrm{H}), 8.32(\mathrm{~s}, 1 \mathrm{H}), 7.62(\mathrm{~m}, 1 \mathrm{H}), 7.22(\mathrm{~m}, 3 \mathrm{H})$, $2.36(\mathrm{~s}, 3 \mathrm{H}) ;{ }^{13} \mathrm{C}$ NMR (ppm, DMSO- $\left.d_{6}\right) \delta 147.0,135.9$, 131.1, 130.7, 128.9, 126.1, 126.0, 19.5; IR (KBr) $v_{\max } / \mathrm{cm}^{-1}$ 3189, 3069, 2991, 2870, 1624, 1599, 1453, 750.

4-N,N-dimethylaminobenzaldehyde oxime (20)

mp 151-153 ${ }^{\circ} \mathrm{C} ;{ }^{1} \mathrm{H} \mathrm{NMR}$ (ppm, $\mathrm{CDCl}_{3}$ ) $\delta 7.98$ (s, 1H), 7.42 (d, 2H, $\left.{ }^{3} \mathrm{~J} 8.8 \mathrm{~Hz}\right), 6.70$ (d, 2H, $\left.{ }^{3} \mathrm{~J} 8.8 \mathrm{~Hz}\right), 2.94$ (s, $6 \mathrm{H}) ;{ }^{13} \mathrm{C} \mathrm{NMR}\left(\mathrm{ppm}, \mathrm{CDCl}_{3}\right) \delta 151.7,149.0,128.2,121.5$, 112.4, 40.0; IR (KBr) $v_{\max } / \mathrm{cm}^{-1} 3243,3138,2985,2913$, 1609, 1556, 1445, 1361.

4-Methoxybenzaldehyde oxime (21)

mp 131-133 ${ }^{\circ} \mathrm{C} ;{ }^{1} \mathrm{H}$ NMR (ppm, DMSO- $\left.d_{6}\right) \delta 8.13(\mathrm{~s}$, 1H), 7.75 (d, 2H, $\left.{ }^{3} J 8.6 \mathrm{~Hz}\right), 6.91\left(\mathrm{~d}, 2 \mathrm{H},{ }^{3} J 8.6 \mathrm{~Hz}\right), 3.85$ $(\mathrm{s}, 3 \mathrm{H}) ;{ }^{13} \mathrm{C}$ NMR (ppm, DMSO- $\left.d_{6}\right) \delta 160.1,147.6,127.8$, 125.6; 114.2, 55.2; IR (KBr) $v_{\max } / \mathrm{cm}^{-1} 3307,3006,2966$, 2838, 1608, 1574,1466, 1252 .

Pyridine-2-carboxylaldehyde oxime(22)

mp 110-112 ${ }^{\circ} \mathrm{C} ;{ }^{1} \mathrm{H}$ NMR (ppm, $\left.\mathrm{CDCl}_{3}\right) \delta 8.64(\mathrm{~m}$, $1 \mathrm{H}), 8.34(\mathrm{~s}, 1 \mathrm{H}), 7.80(\mathrm{~m}, 1 \mathrm{H}), 7.73(\mathrm{~m}, 1 \mathrm{H}), 7.30(\mathrm{~m}$, $1 \mathrm{H}) ;{ }^{13} \mathrm{C} \mathrm{NMR}\left(\mathrm{ppm}, \mathrm{CDCl}_{3}\right) \delta 151.8,150.2,149.3,136.8$, 124.0, 121.0; IR (KBr) $v_{\max } / \mathrm{cm}^{-1} 3285,3187-3005,1653$, 1593-1472, 1322, 737.
Furane-2-carboxyaldehyde oxime (23)

mp 71-73 ${ }^{\circ} \mathrm{C} ;{ }^{1} \mathrm{H}$ NMR (ppm, $\left.\mathrm{CDCl}_{3}\right) \delta 7.54(\mathrm{~s}, 1 \mathrm{H})$, 7.47 (dd, $\left.1 \mathrm{H},{ }^{3} \mathrm{~J} 1.7,{ }^{4} \mathrm{~J} 0.6 \mathrm{~Hz}\right), 7.35\left(\mathrm{dd}, 1 \mathrm{H},{ }^{3} \mathrm{~J} 3.5,{ }^{4} \mathrm{~J} 0 \mathrm{~Hz}\right.$ ), $6.53\left(\mathrm{dd}, 1 \mathrm{H},{ }^{3} \mathrm{~J} 3.5,{ }^{3} \mathrm{~J} 1.7 \mathrm{~Hz}\right) ;{ }^{13} \mathrm{C} \mathrm{NMR}\left(\mathrm{ppm}, \mathrm{CDCl}_{3}\right.$ ) $\delta 145.1,143.4,137.0,118.2,112.3$; IR $(\mathrm{KBr}) v_{\max } / \mathrm{cm}^{-1}$ 3165, 3080-3042, 1645, 1567-1477, 1449, 750.

Thiophene-2-carboxylaldehyde oxime (24)

mp 135-137 ${ }^{\circ} \mathrm{C} ;{ }^{1} \mathrm{H}$ NMR (ppm, DMSO- $\left.d_{6}\right) \delta 11.86$ (s, 1H), $7.84(\mathrm{~s}, 1 \mathrm{H}), 7.73\left(\mathrm{~d}, 1 \mathrm{H},{ }^{3} \mathrm{~J} 3.9 \mathrm{~Hz}\right), 7.47(\mathrm{~d}, 1 \mathrm{H}$, $\left.{ }^{3} J 3.9 \mathrm{~Hz}\right), 7.12(\mathrm{t}, 1 \mathrm{H}) ;{ }^{13} \mathrm{C} \mathrm{NMR}\left(\mathrm{ppm}, \mathrm{DMSO}-d_{6}\right) \delta 139.8$, 131.1, 131.0, 131.0, 126.2; IR (KBr) $v_{\max } / \mathrm{cm}^{-1} 3121,3017$, $1632,1507-1435$.

Pyrrol-2-carboxyaldehyde oxime (25)

mp 183-185 ${ }^{\circ} \mathrm{C} ;{ }^{1} \mathrm{H}-\mathrm{NMR}$ (ppm, DMSO- $\left.d_{6}\right) \delta 11.14$ (s, 1H), 7.26 (s, 1H), 6.88 (d, 1H, $\left.{ }^{3} \mathrm{~J} 3.2 \mathrm{~Hz}\right), 6.55$ (d, 1H, $\left.{ }^{3} J 3.2 \mathrm{~Hz}\right), 6.10(\mathrm{t}, 1 \mathrm{H}), 3.37(\mathrm{~s}, 1 \mathrm{H}) ;{ }^{13} \mathrm{C} \mathrm{NMR}$ (ppm, DMSO- $\left.d_{6}\right) \delta 137.1,129.4,120.8,113.8,108.3$; IR (KBr) $\mathrm{V}_{\max } / \mathrm{cm}^{-1} 3426,3419,3033,1646,1586,1461,1429,1304$, 834,745 .

1-Methylimidazole-2-carboxyaldehyde oxime (26)

mp $169-171^{\circ} \mathrm{C} ;{ }^{1} \mathrm{H}$ NMR (ppm, DMSO- $d_{6}$ ) $\delta 11.59$ (s, 1H), 8.06 (s, 1H), 7.24 (d, 1H, $\left.{ }^{3} J 3.0 \mathrm{~Hz}\right), 6.98(\mathrm{~d}, 1 \mathrm{H}$, ${ }^{3} J 3.0 \mathrm{~Hz}$ ), 3.80 (s, $\left.3 \mathrm{H}\right) ;{ }^{13} \mathrm{C} \mathrm{NMR}\left(\mathrm{ppm}, \mathrm{DMSO}-d_{6}\right) \delta 141.4$, 140.2, 128.5, 124.6, 34.8; IR (KBr) $v_{\max } / \mathrm{cm}^{-1} 3413,3118$ 3078, 2994-2917, 1628, 1556-1523-1477, 1357.

*e-mail: figueroa@ime.eb.br 

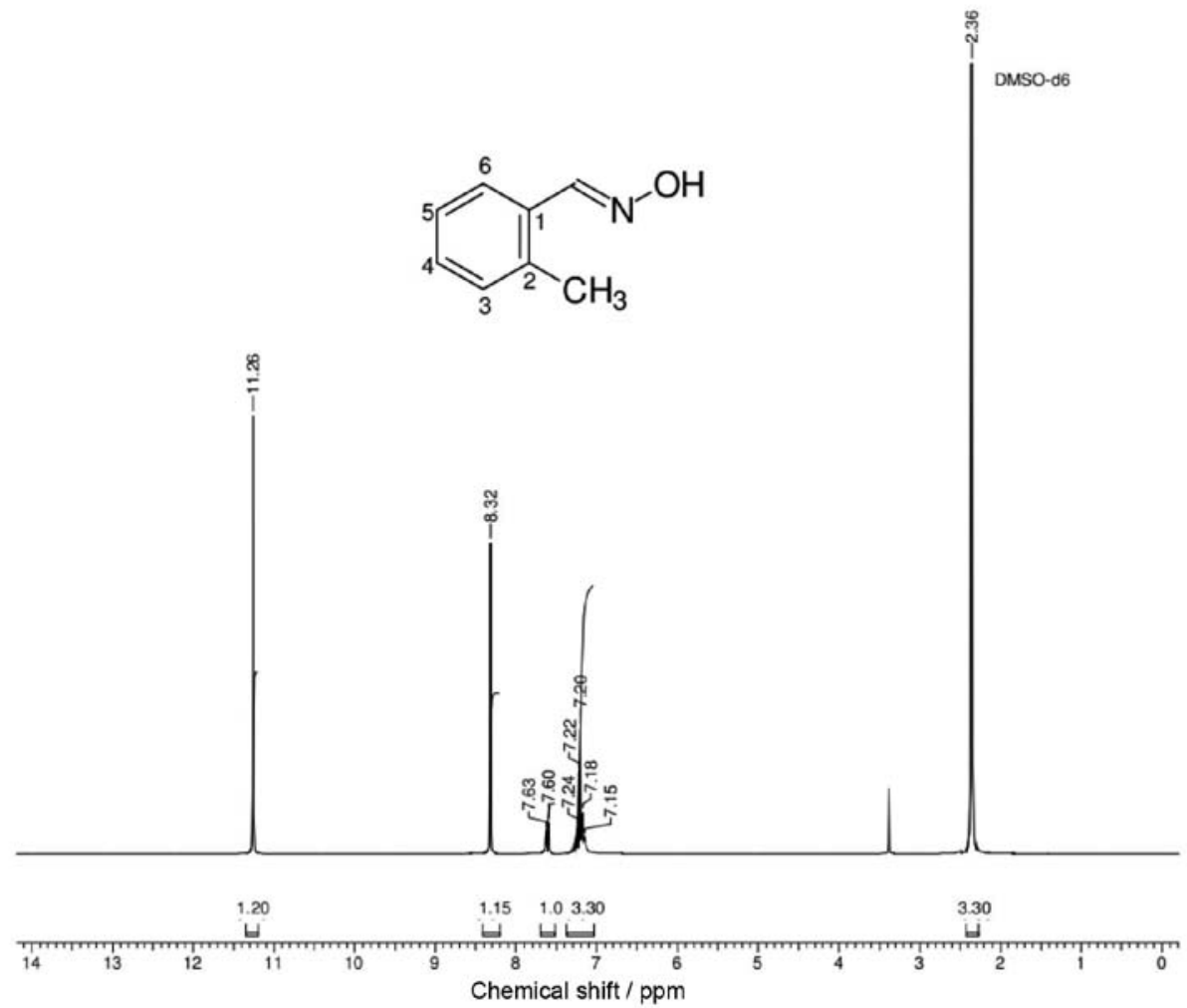

Figure S1. ${ }^{1} \mathrm{H}$ NMR (300 MHz, DMSO- $d_{6}$ ) of 2-methylbenzaldehyde oxime (16).

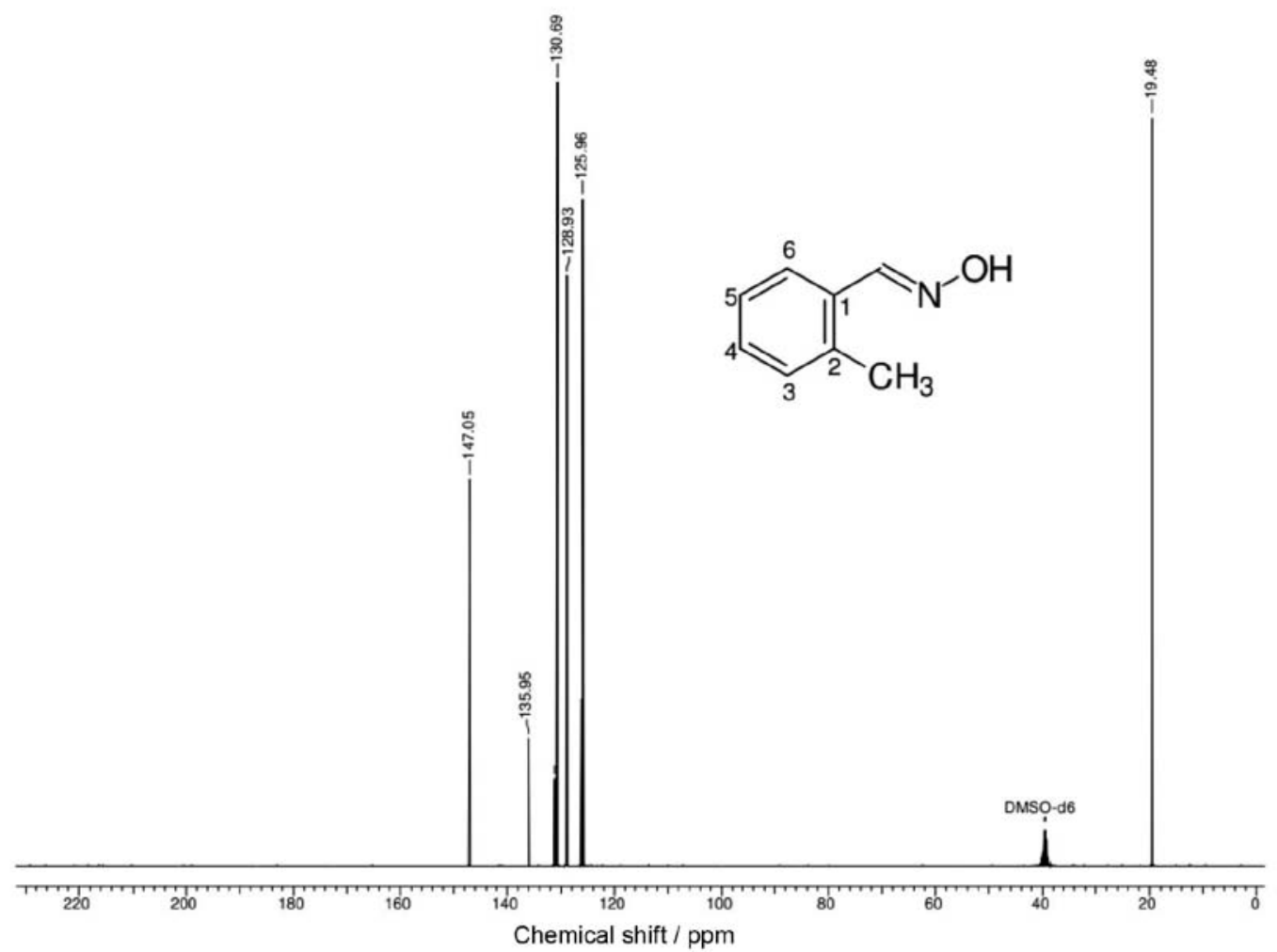

Figure S2. ${ }^{13} \mathrm{C}$ NMR (75 MHz, DMSO- $d_{6}$ ) of 2-methylbenzaldehyde oxime (16). 


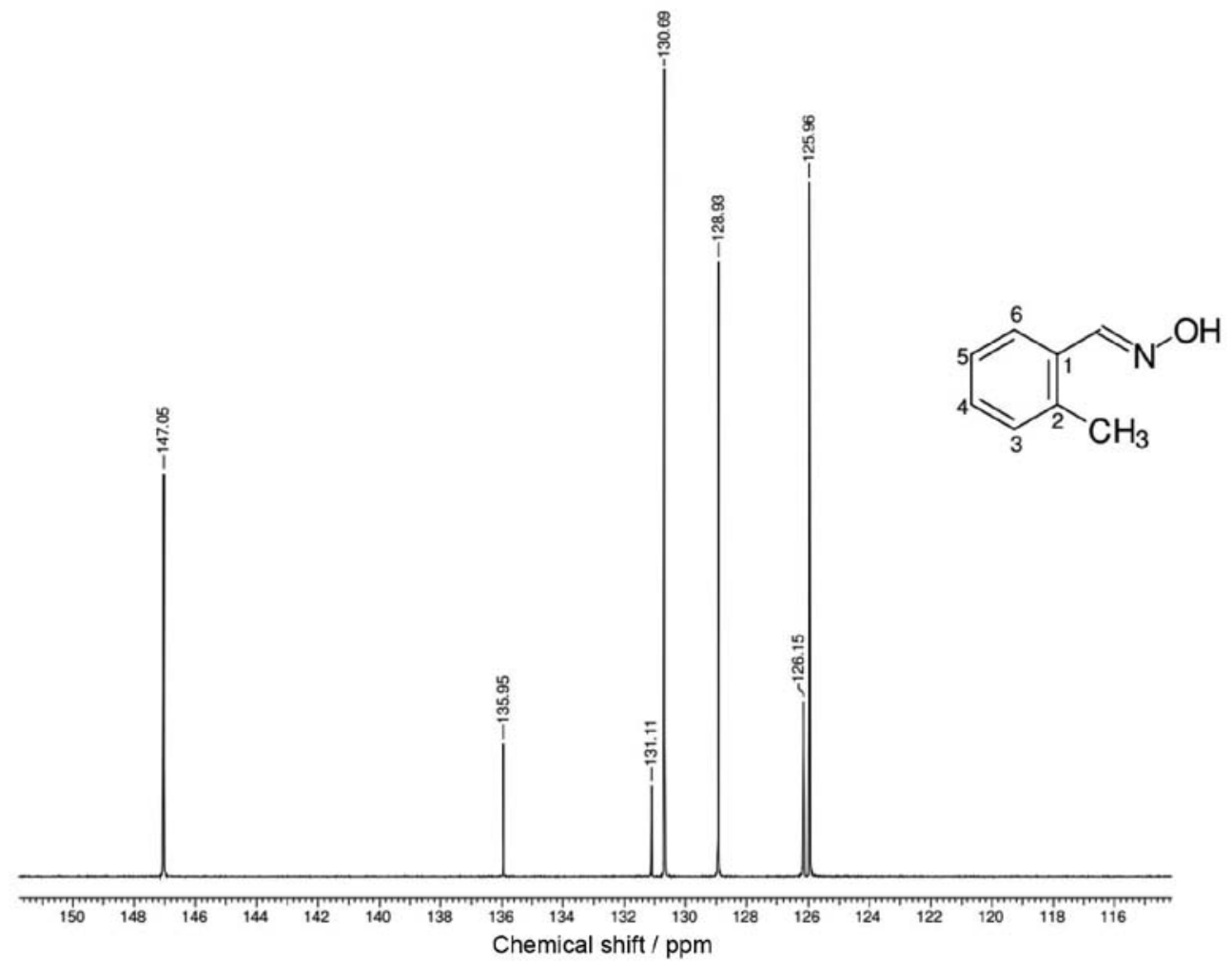

Figure S3. Expansion of ${ }^{13} \mathrm{C}$ NMR (75 MHz, DMSO- $d_{6}$ ) of 2-methylbenzaldehyde oxime (16).<smiles>O=[N+]([O-])c1cccc(/C=N/O)c1O</smiles><smiles>C1CCCCC1</smiles>

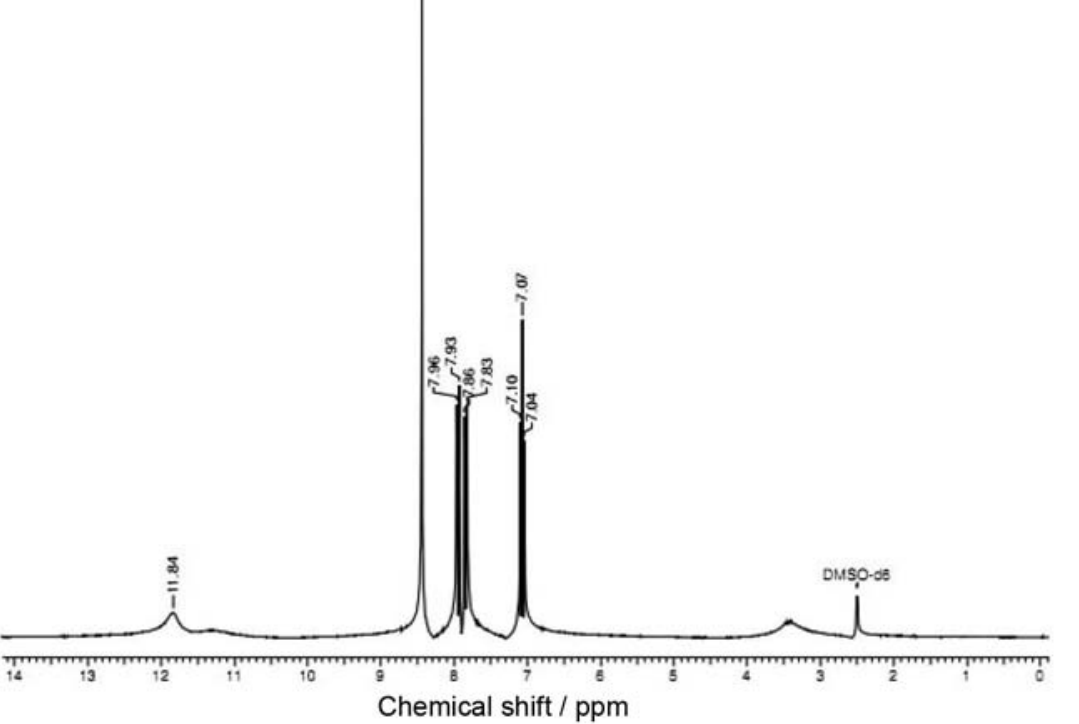

Figure S4. ${ }^{1} \mathrm{H}$ NMR $\left(300 \mathrm{MHz}\right.$, DMSO- $\left.d_{6}\right)$ of 3-nitrosalicylaldehyde oxime (17). 


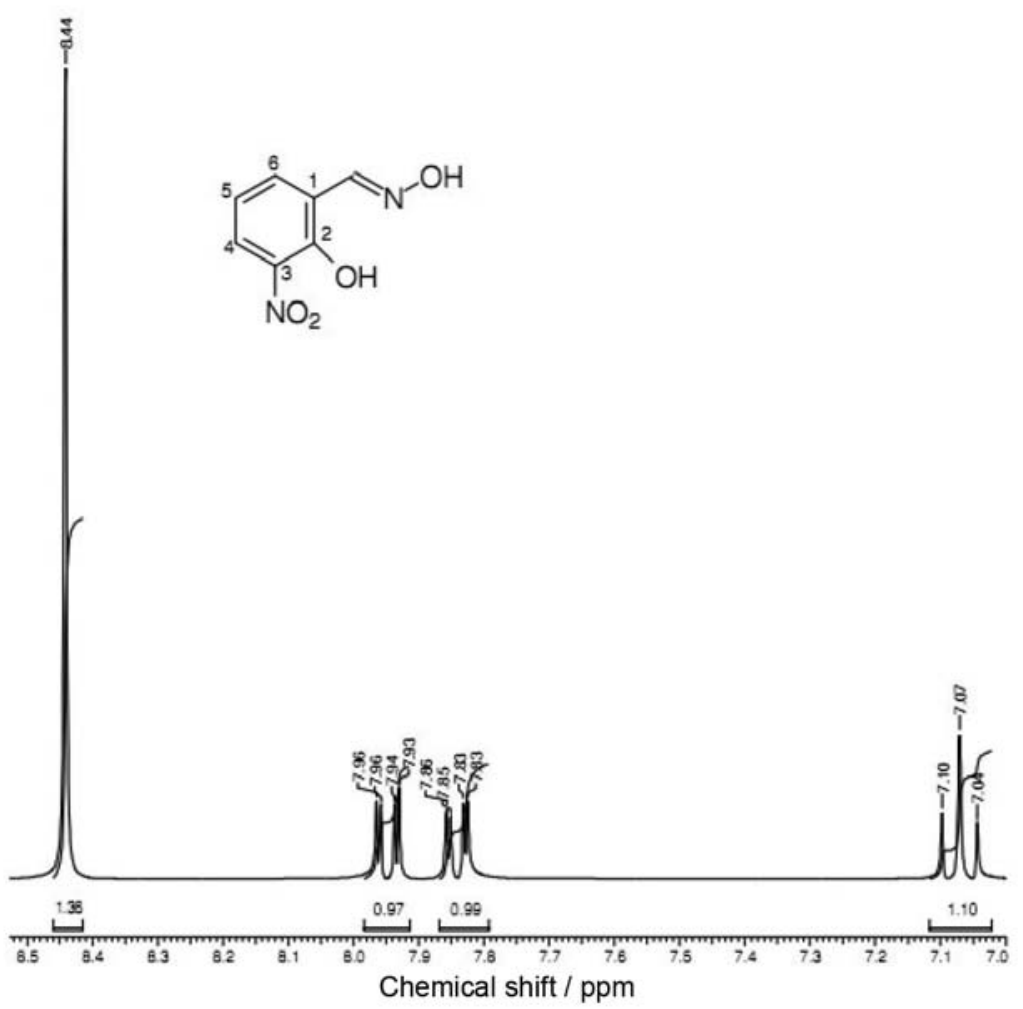

Figure S5. Expansion of ${ }^{1} \mathrm{H}$ NMR (300 MHz, DMSO- $d_{6}$ ) of 3-nitrosalicylaldehyde oxime (17).

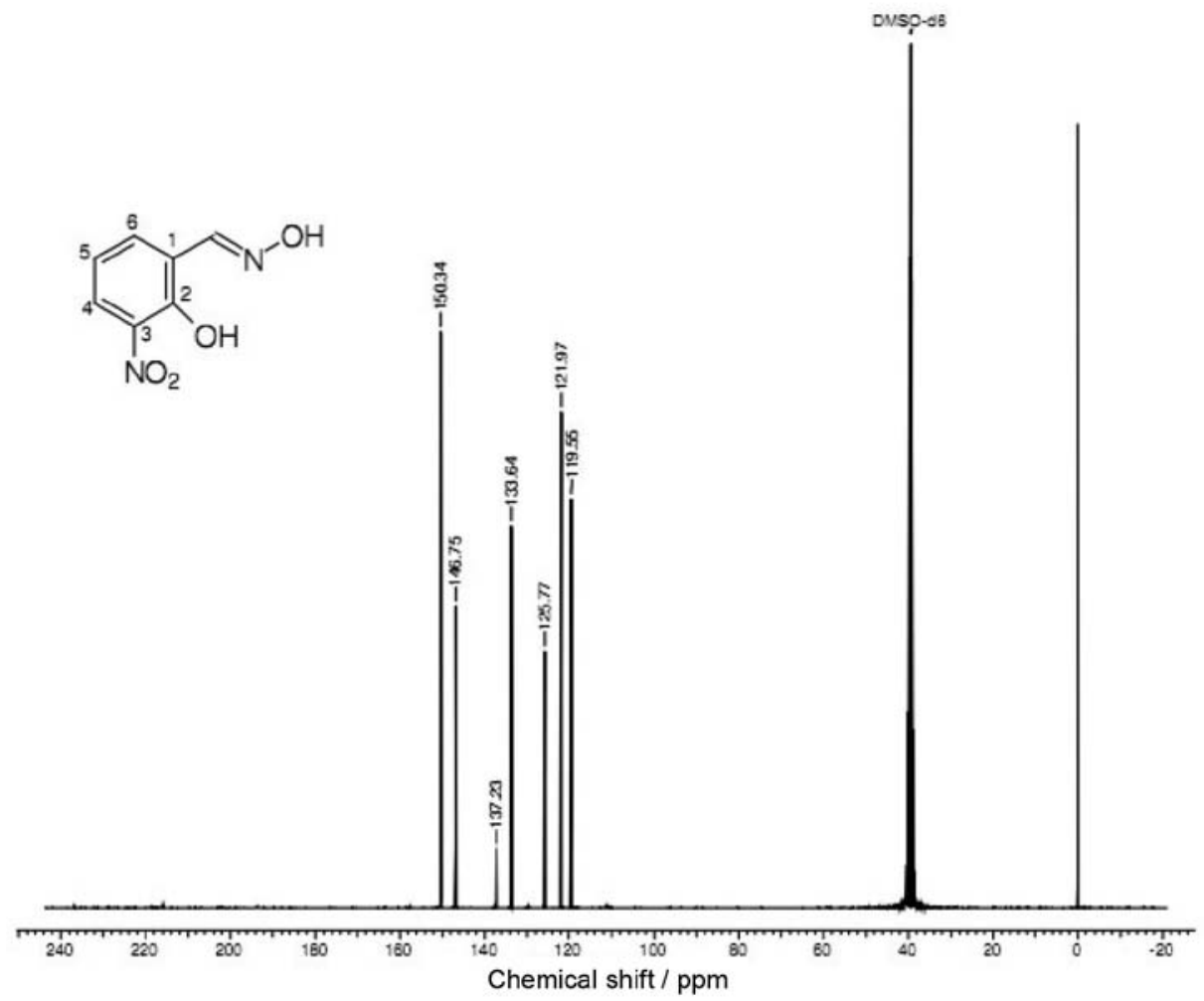

Figure S6. ${ }^{13} \mathrm{C}$ NMR (75 MHz, DMSO- $d_{6}$ ) of 3-nitrosalicylaldehyde oxime (17). 


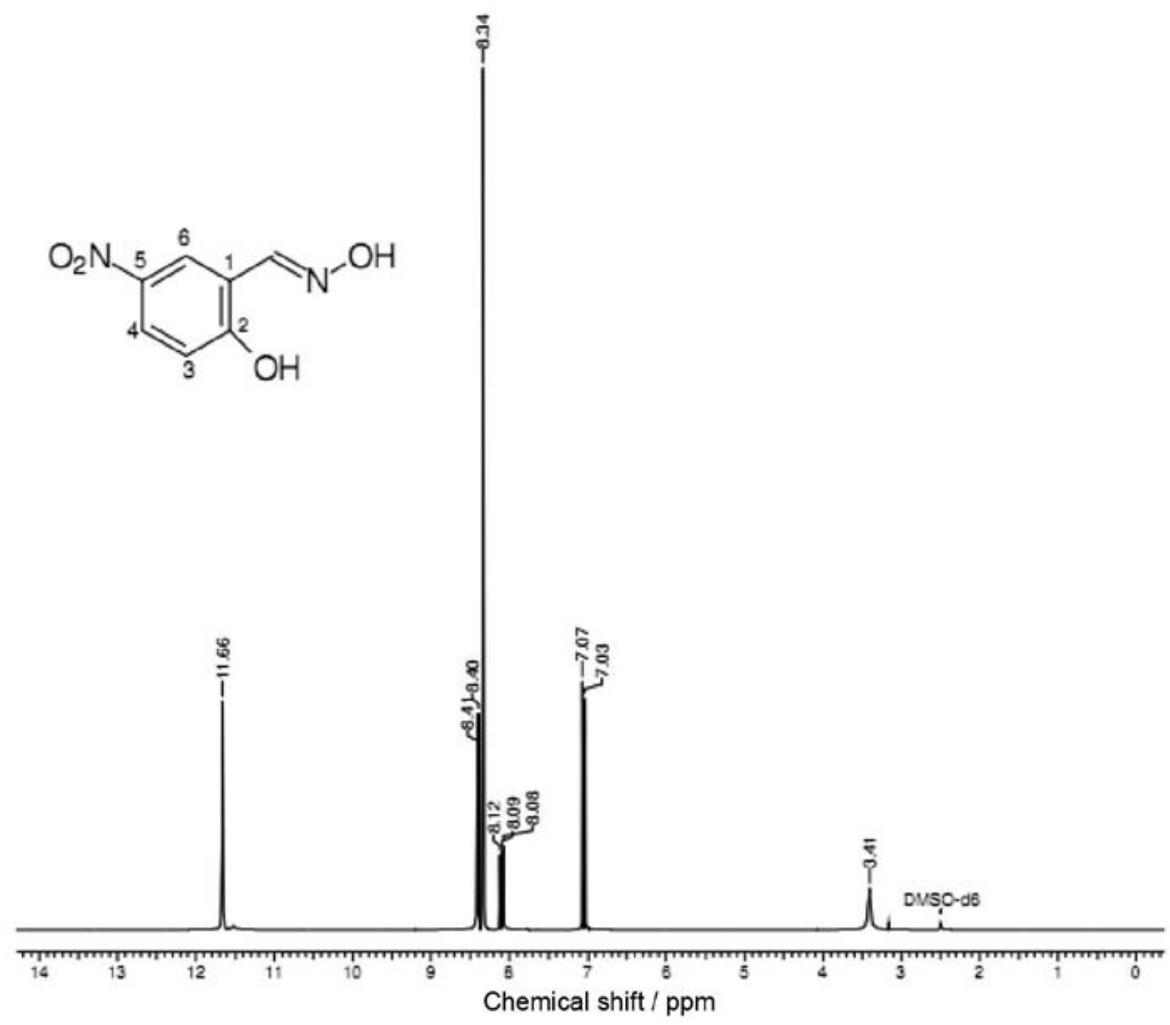

Figure S7. ${ }^{1} \mathrm{H}$ NMR (300 MHz, DMSO- $d_{6}$ ) of 5-nitrosalicylaldehyde oxime (18).

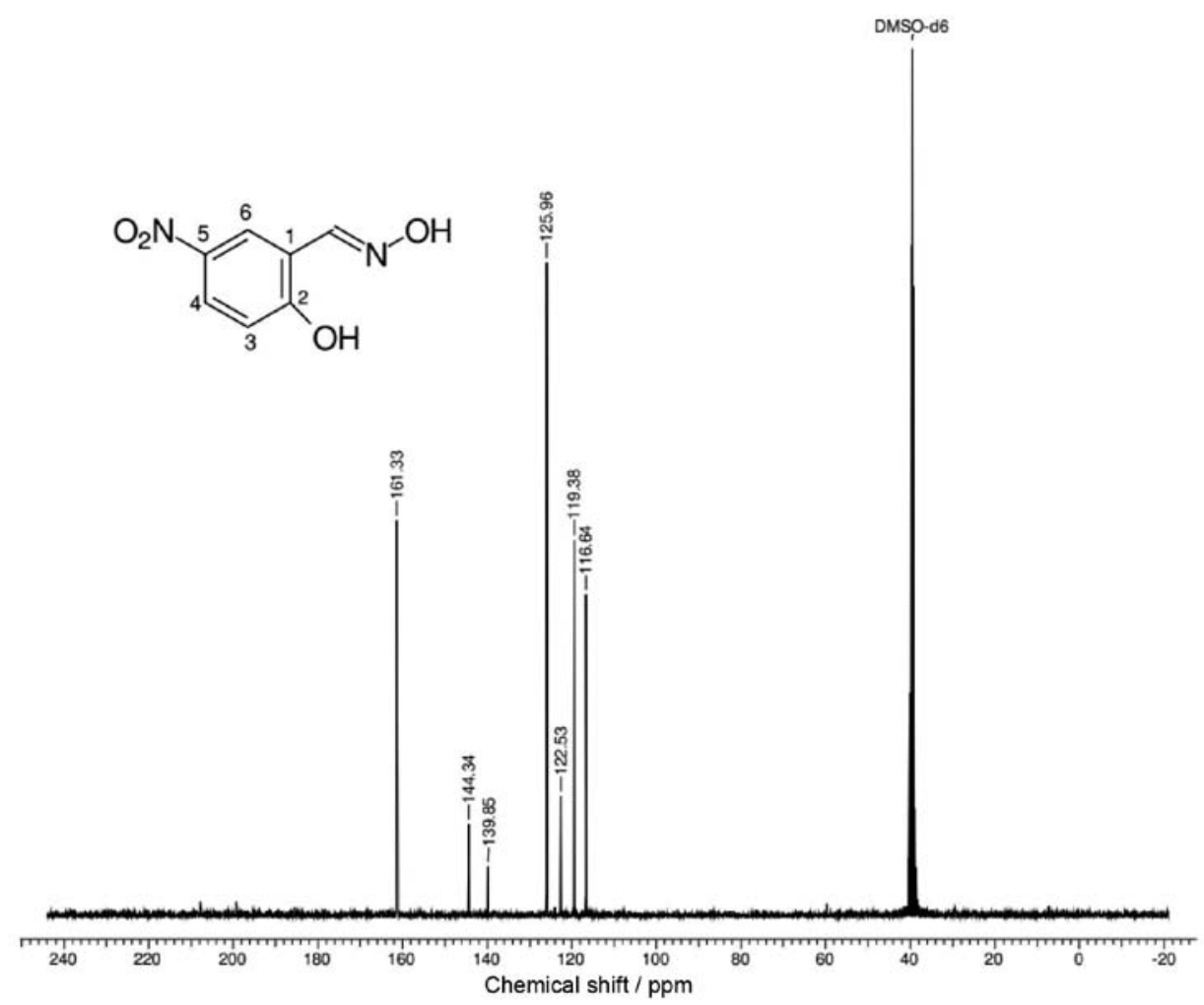

Figure S8. ${ }^{13} \mathrm{C}$ NMR (75 MHz, DMSO- $d_{6}$ ) of 5-nitrosalicylaldehyde oxime (18). 


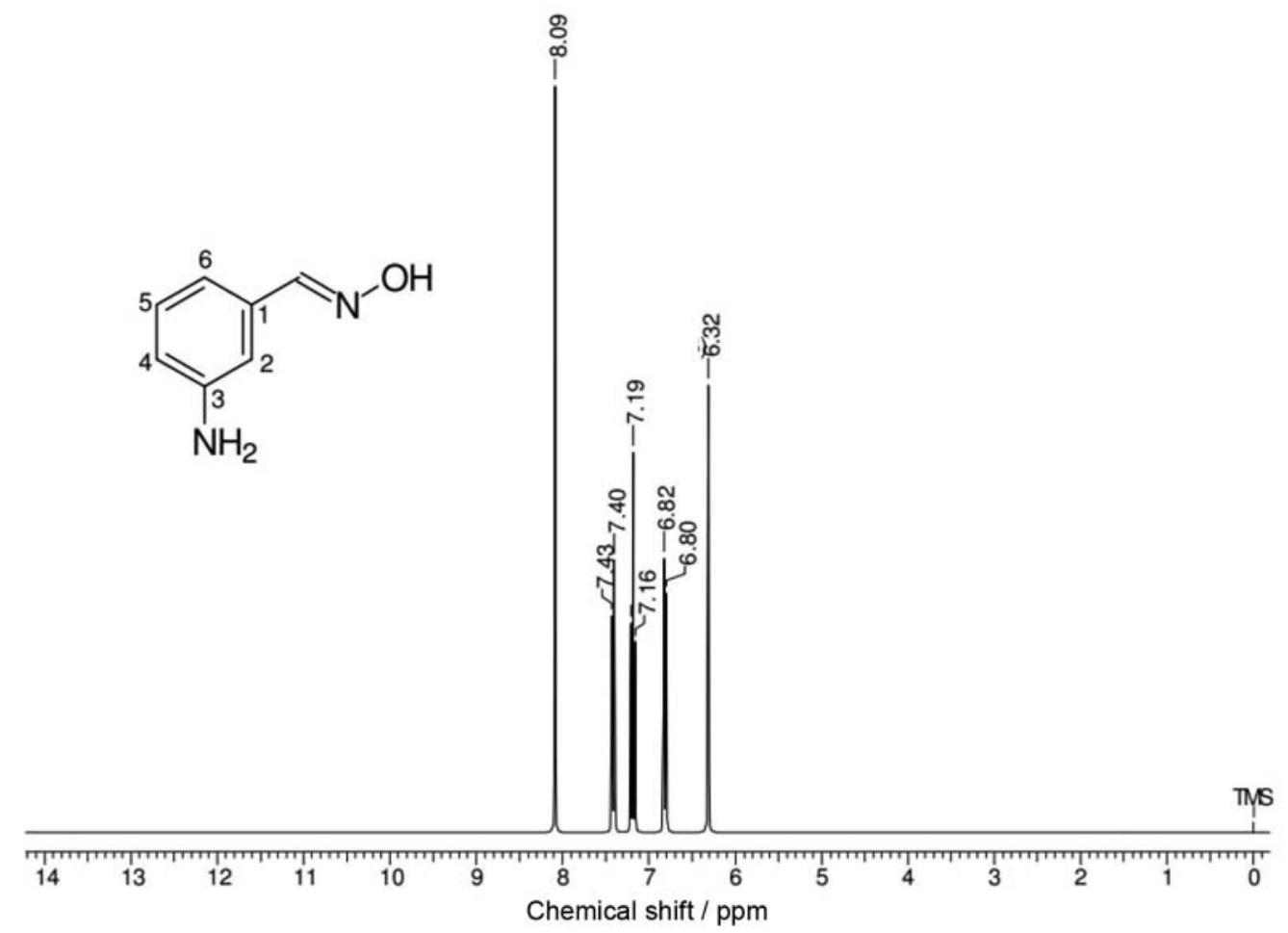

Figure S9. ${ }^{1} \mathrm{H}$ NMR (300 MHz, $\mathrm{CDCl}_{3}$ ) of 3-aminobenzaldehyde oxime (19).

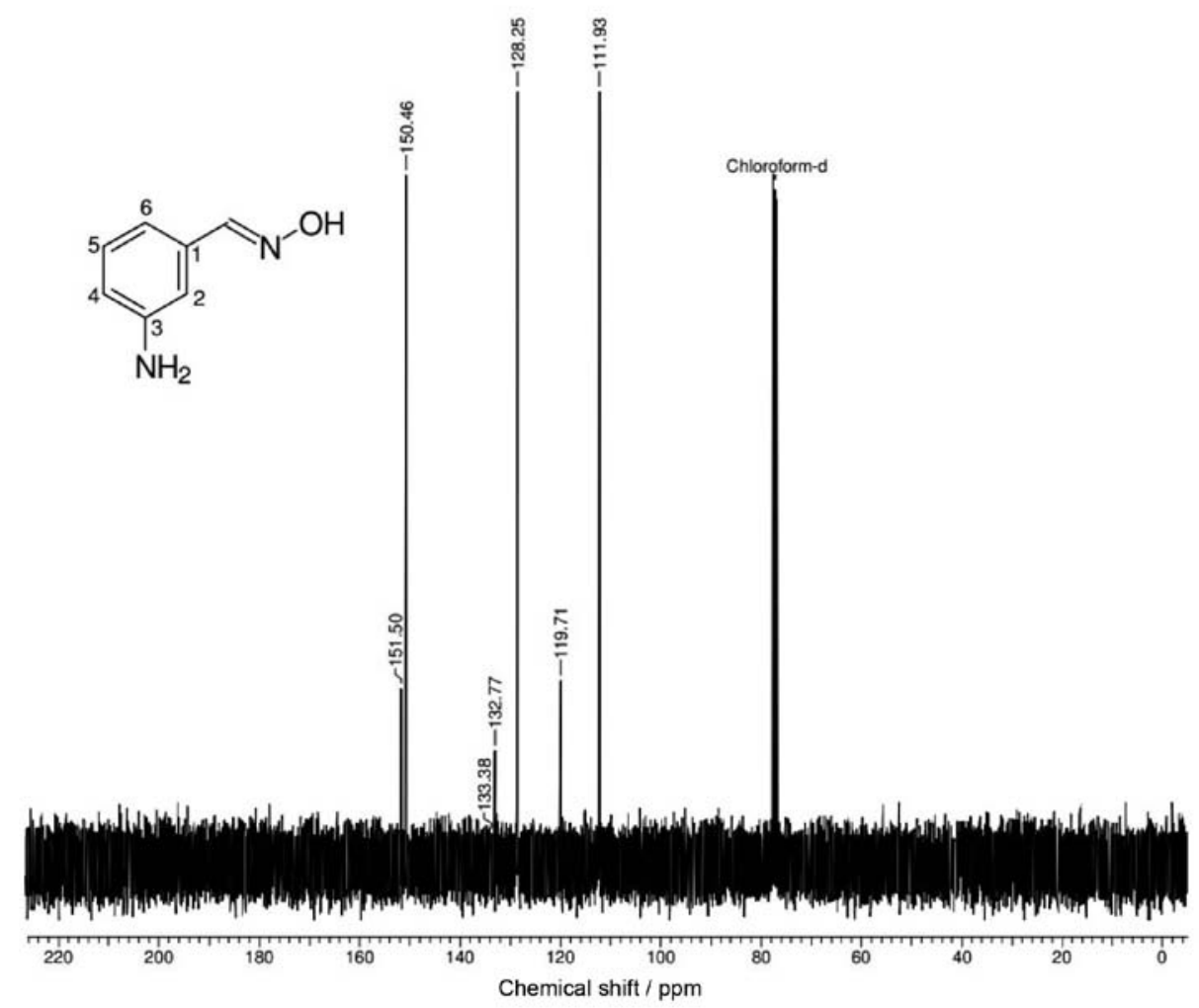

Figure S10. ${ }^{13} \mathrm{C}$ NMR (75 MHz, $\mathrm{CDCl}_{3}$ ) of 3-aminobenzaldehyde oxime (19). 


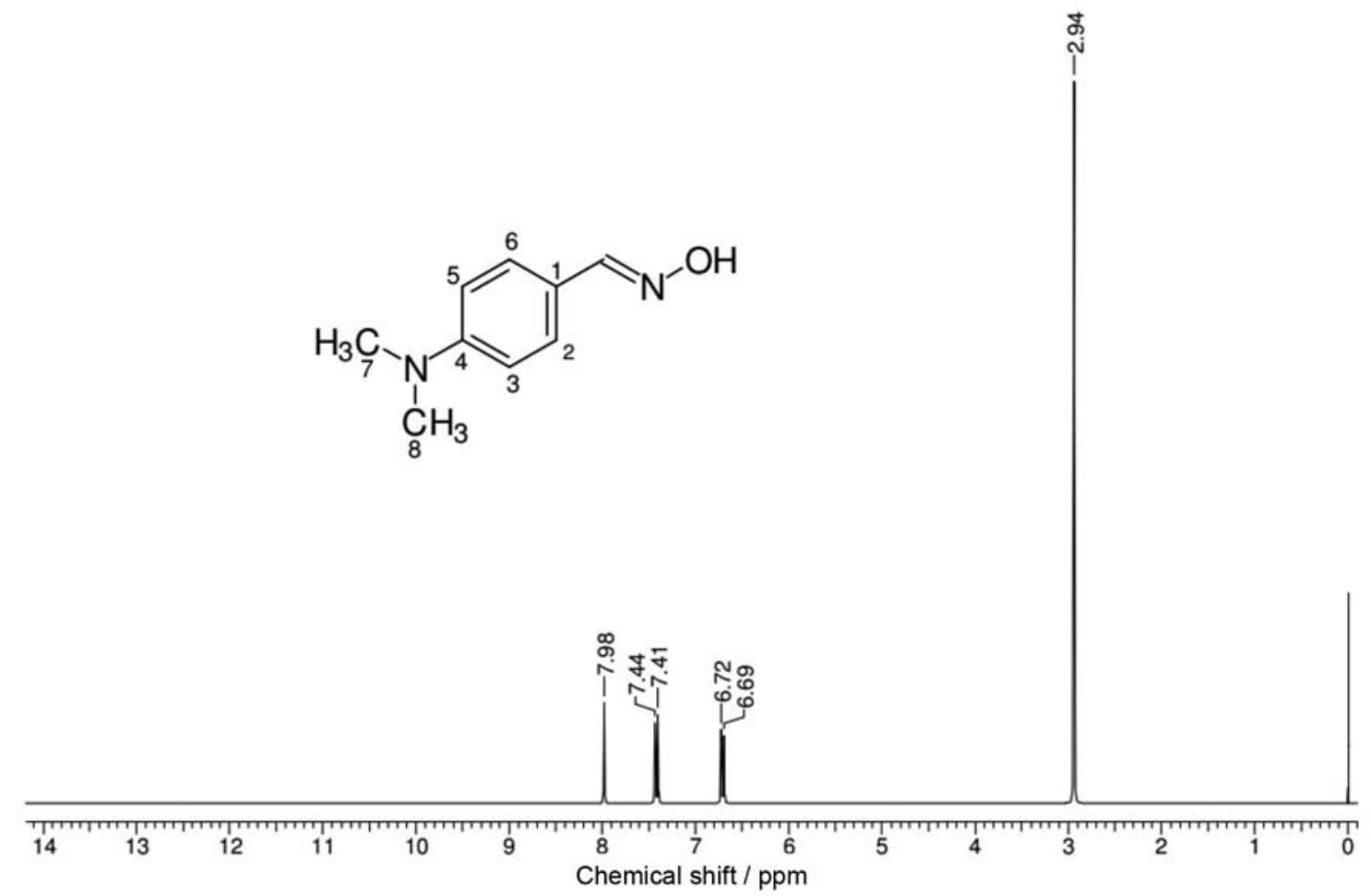

Figure S11. ${ }^{1} \mathrm{H}$ NMR (300 MHz, $\mathrm{CDCl}_{3}$ ) of $4-N, N$-dimethylaminobenzaldehyde oxime (20).

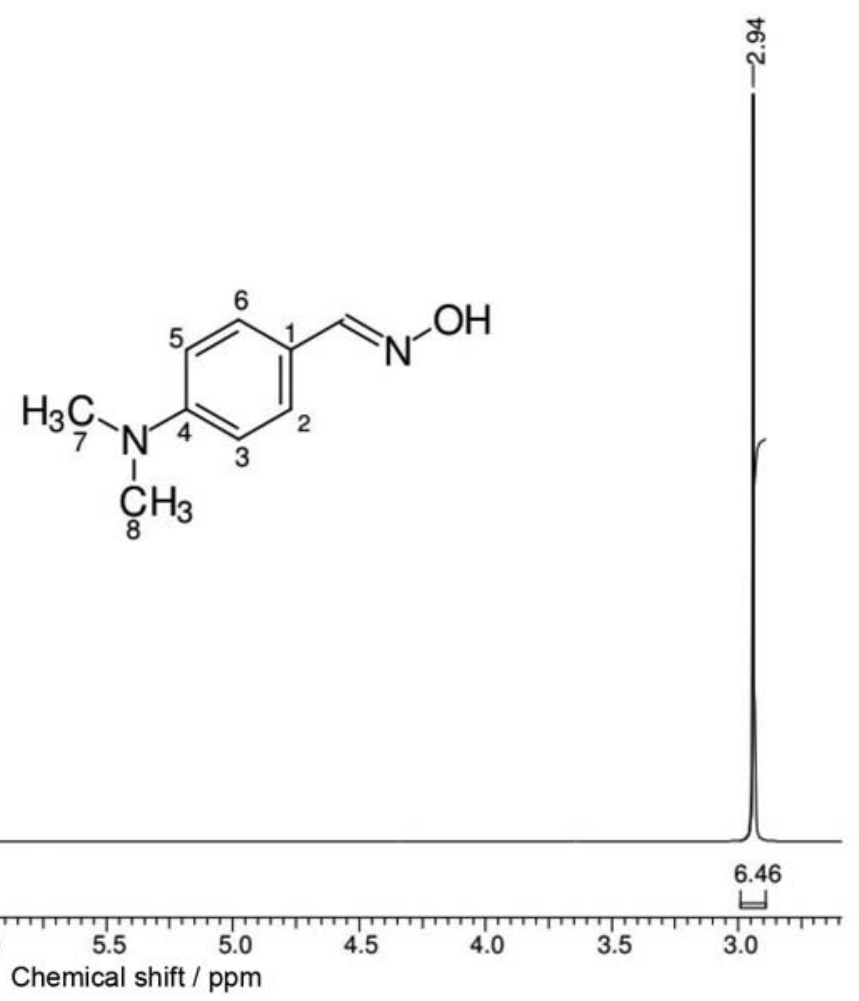

Figure S12. Expansion of ${ }^{1} \mathrm{H}$ NMR (300 MHz, $\mathrm{CDCl}_{3}$ ) of 4- $N, N$-dimethylaminobenzaldehyde oxime (20). 


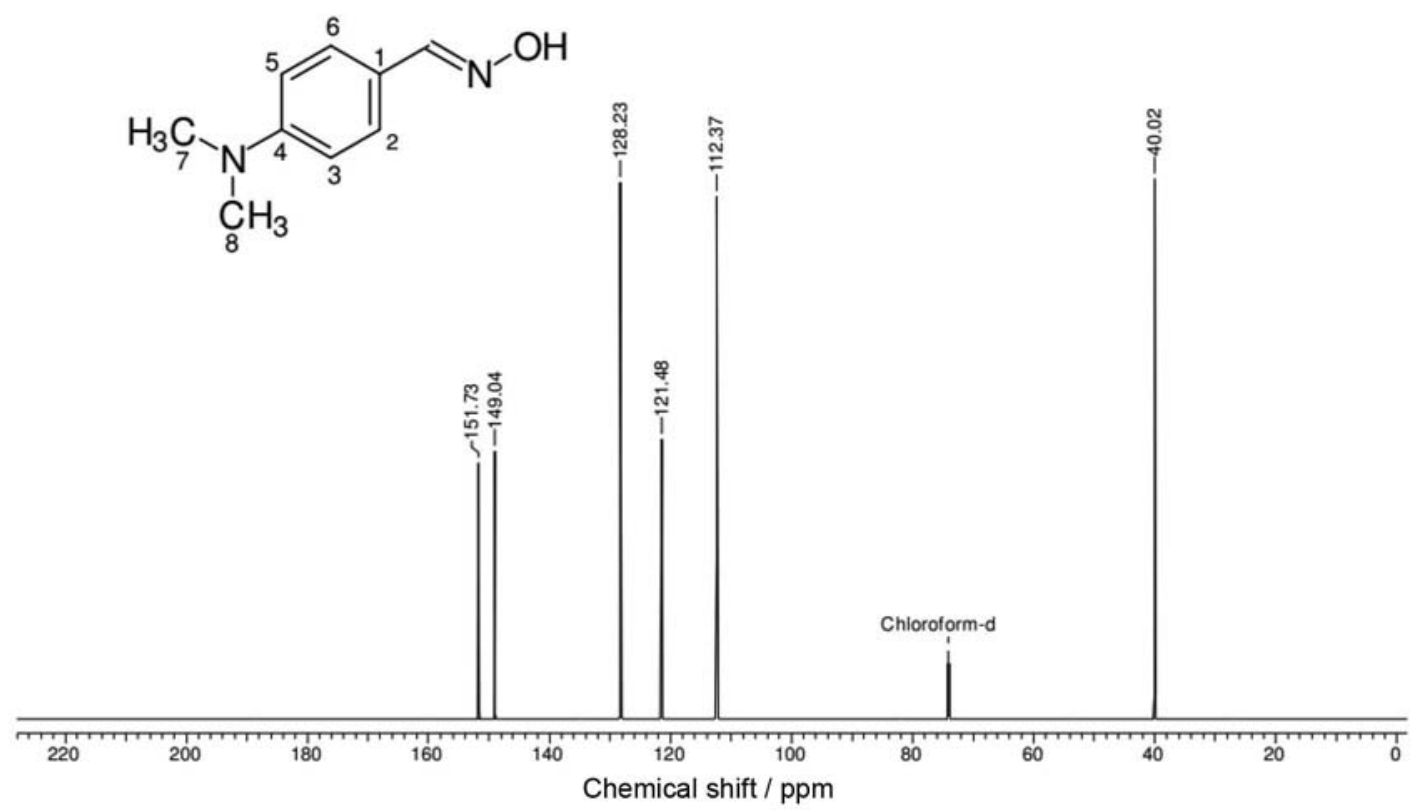

Figure S13. ${ }^{13} \mathrm{C}$ NMR (75 MHz, $\mathrm{CDCl}_{3}$ ) of 4- $N, N$-dimethylaminobenzaldehyde oxime (20).<smiles>COc1ccc(/C=N/O)cc1</smiles>

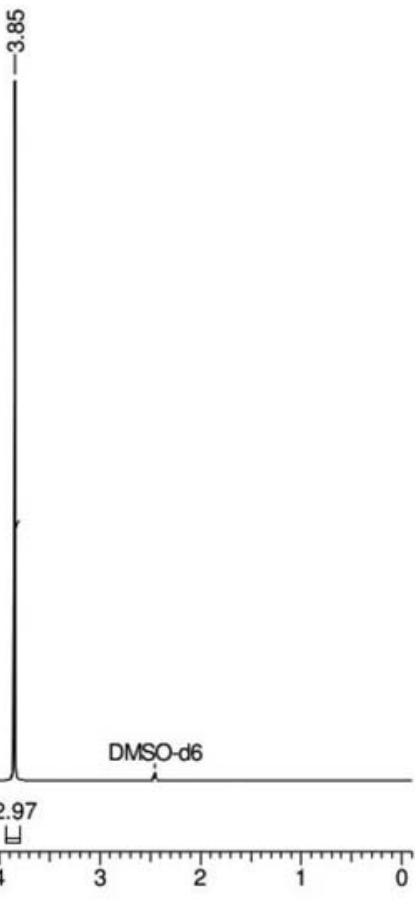

Figure S14. ${ }^{1} \mathrm{H}$ NMR (300 MHz, DMSO- $d_{6}$ ) of 4-methoxybenzaldehyde oxime (21). 


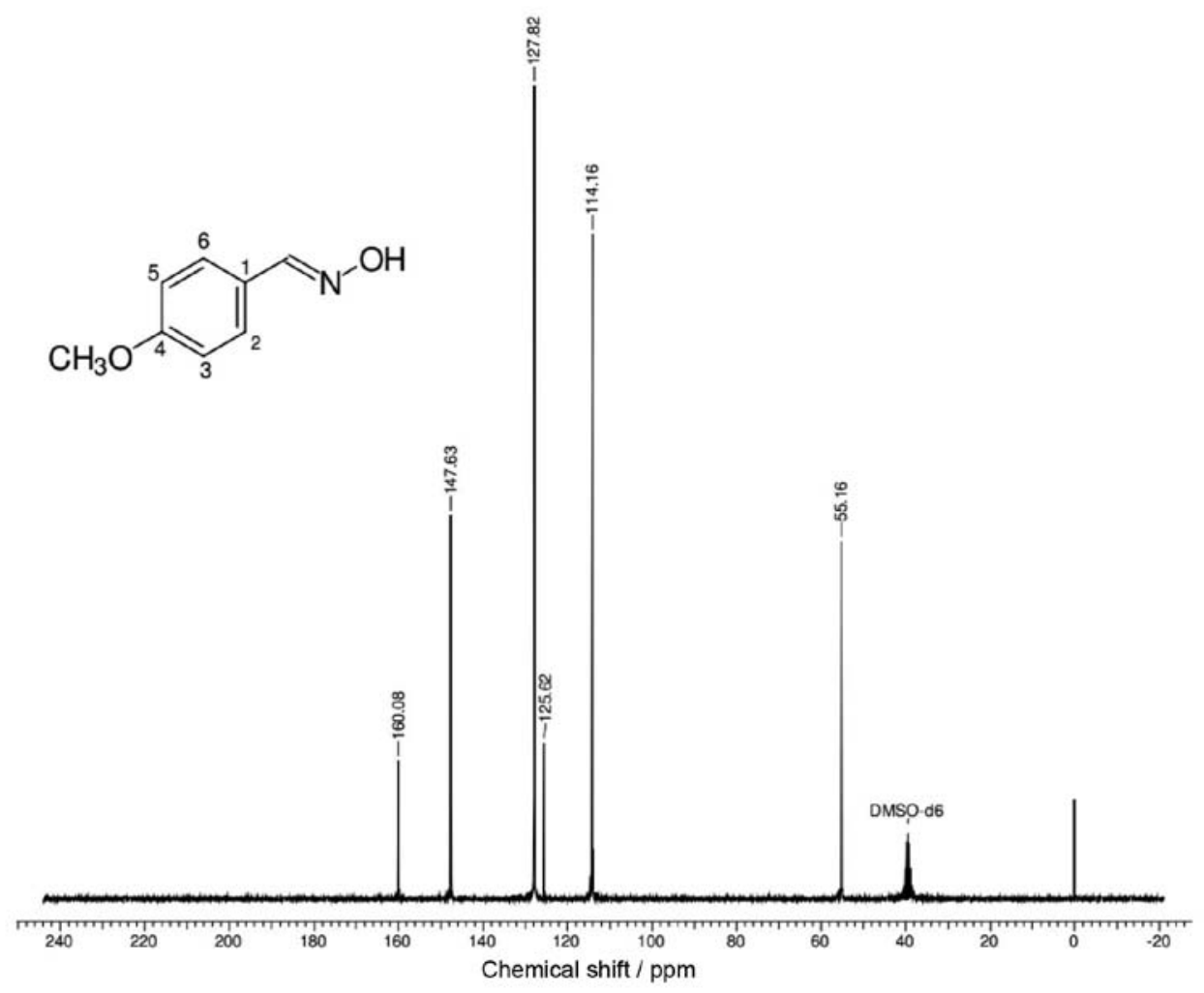

Figure S15. ${ }^{13} \mathrm{C}$ NMR (75 MHz, DMSO- $d_{6}$ ) of 4-methoxybenzaldehyde oxime (21).

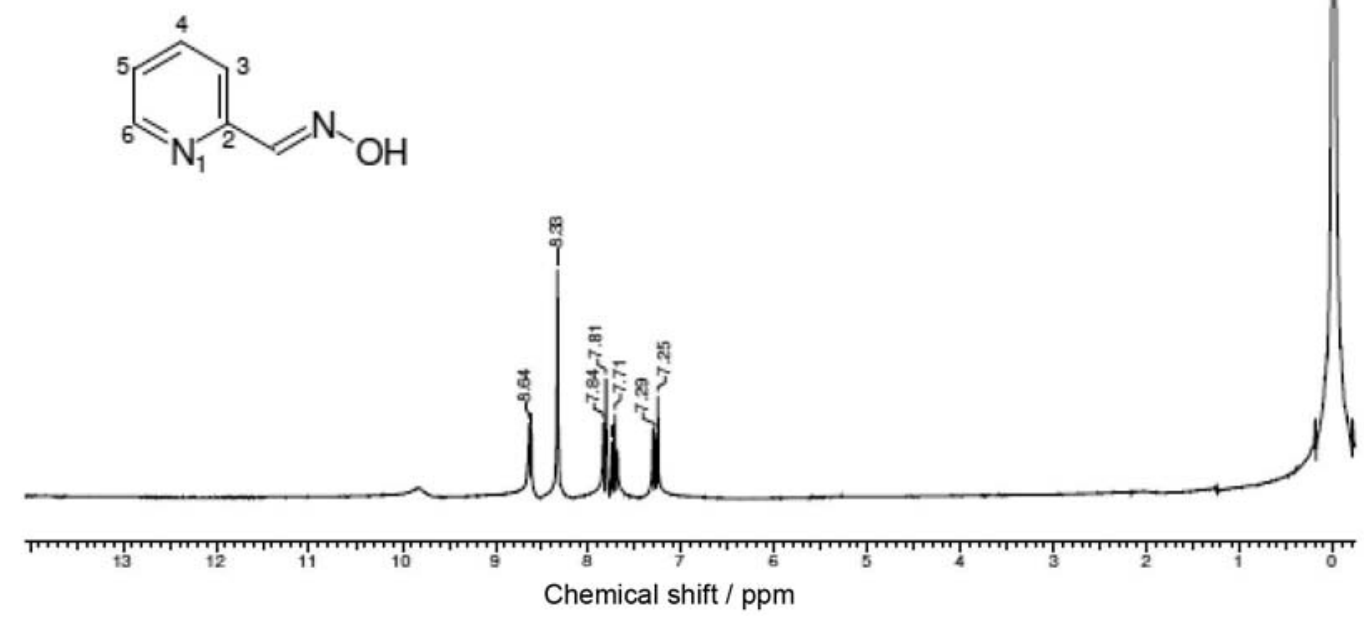

Figure S16. ${ }^{1} \mathrm{H}$ NMR (300 MHz, $\mathrm{CDCl}_{3}$ ) of pyridine-2-carboxyladehyde oxime (22). 


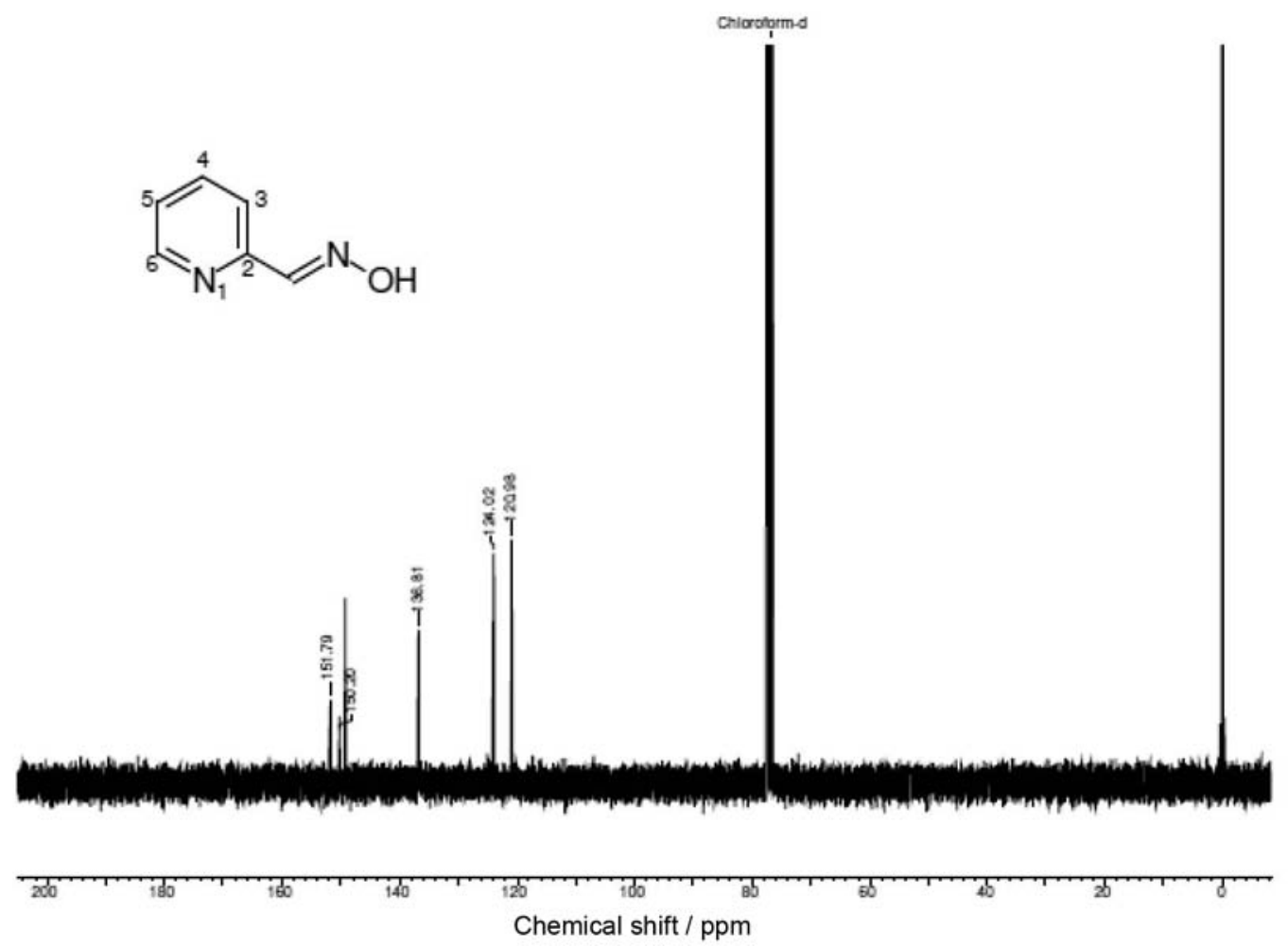

Figure S17. ${ }^{13} \mathrm{C} \mathrm{NMR}\left(75 \mathrm{MHz}, \mathrm{CDCl}_{3}\right.$ ) of pyridine-2-carboxyladehyde oxime (22).<smiles>O/N=C/c1ccccn1</smiles>

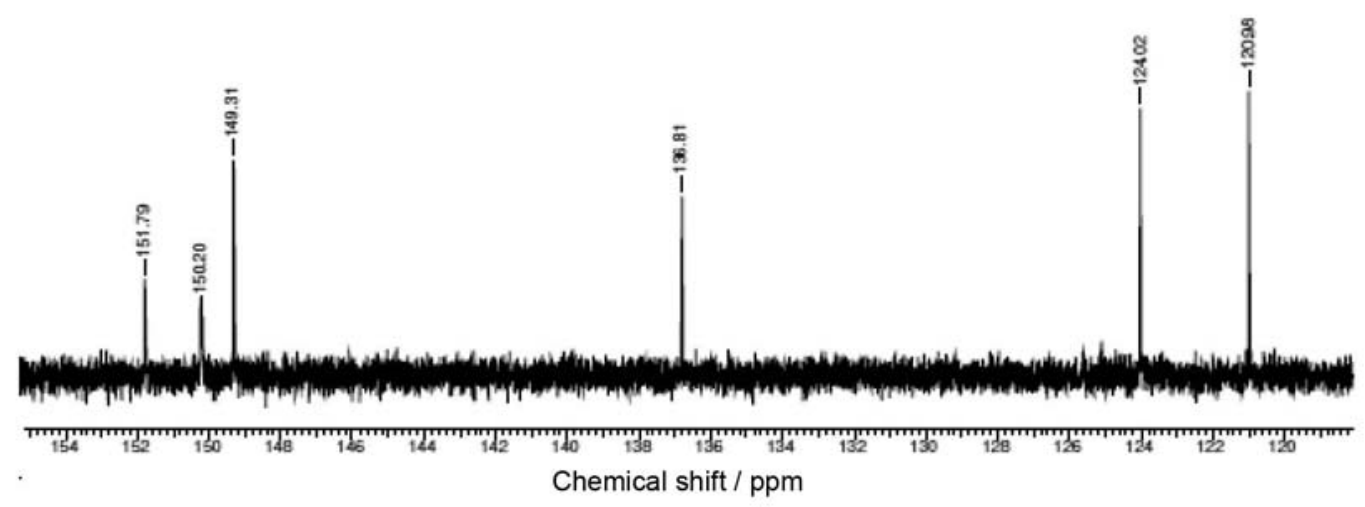

Figure S18. Expansion of ${ }^{13} \mathrm{C}$ NMR (75 MHz, $\mathrm{CDCl}_{3}$ ) of pyridine-2-carboxyladehyde oxime (22). 
<smiles>O/N=C/c1ccco1</smiles>

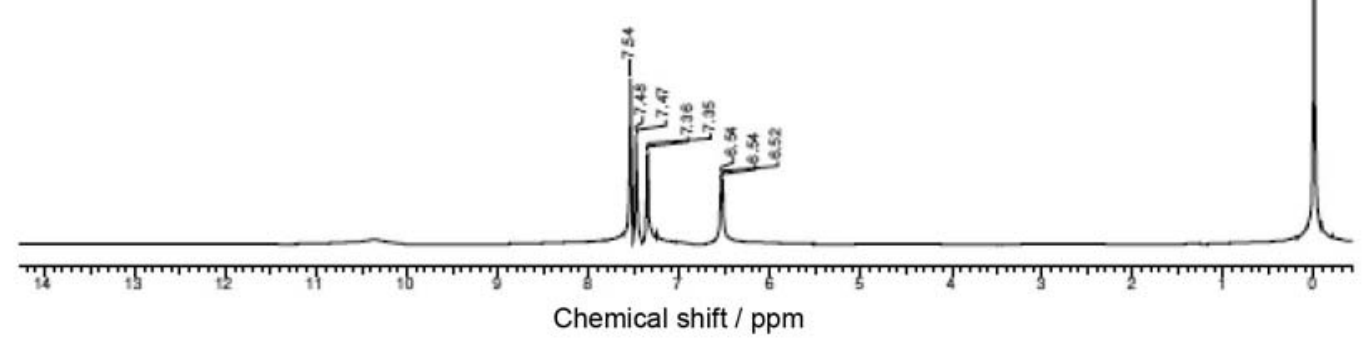

Figure S19. ${ }^{1} \mathrm{H} \mathrm{NMR}\left(300 \mathrm{MHz}, \mathrm{CDCl}_{3}\right.$ ) of furane-2-carboxyaldehyde oxime (23).

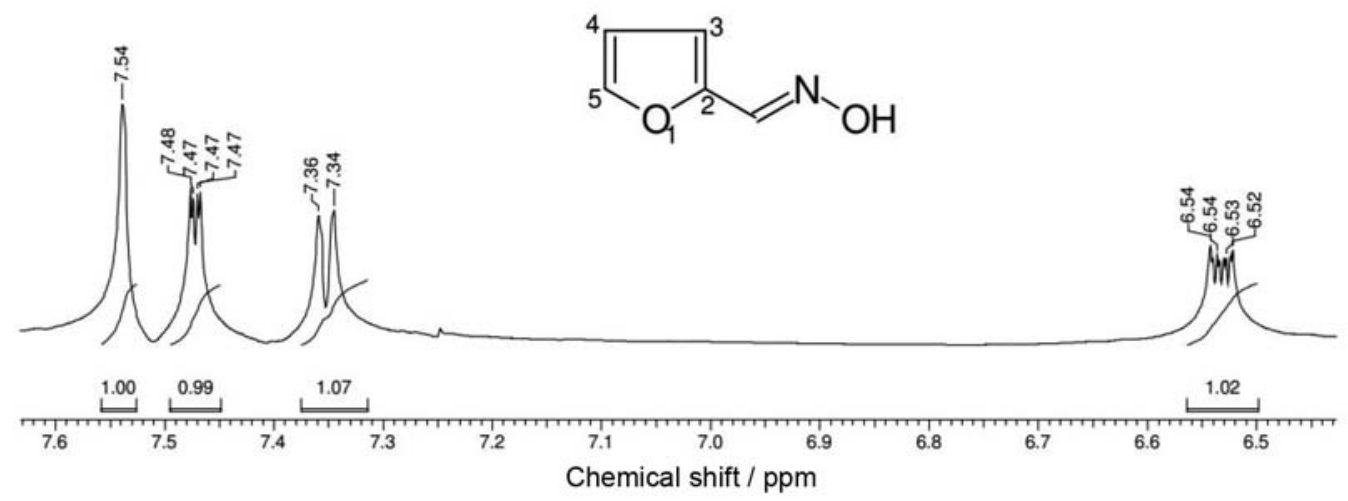

Figure S20. Expansion of ${ }^{1} \mathrm{H}$ NMR (300 MHz, $\mathrm{CDCl}_{3}$ ) of furane-2-carboxyaldehyde oxime (23). 


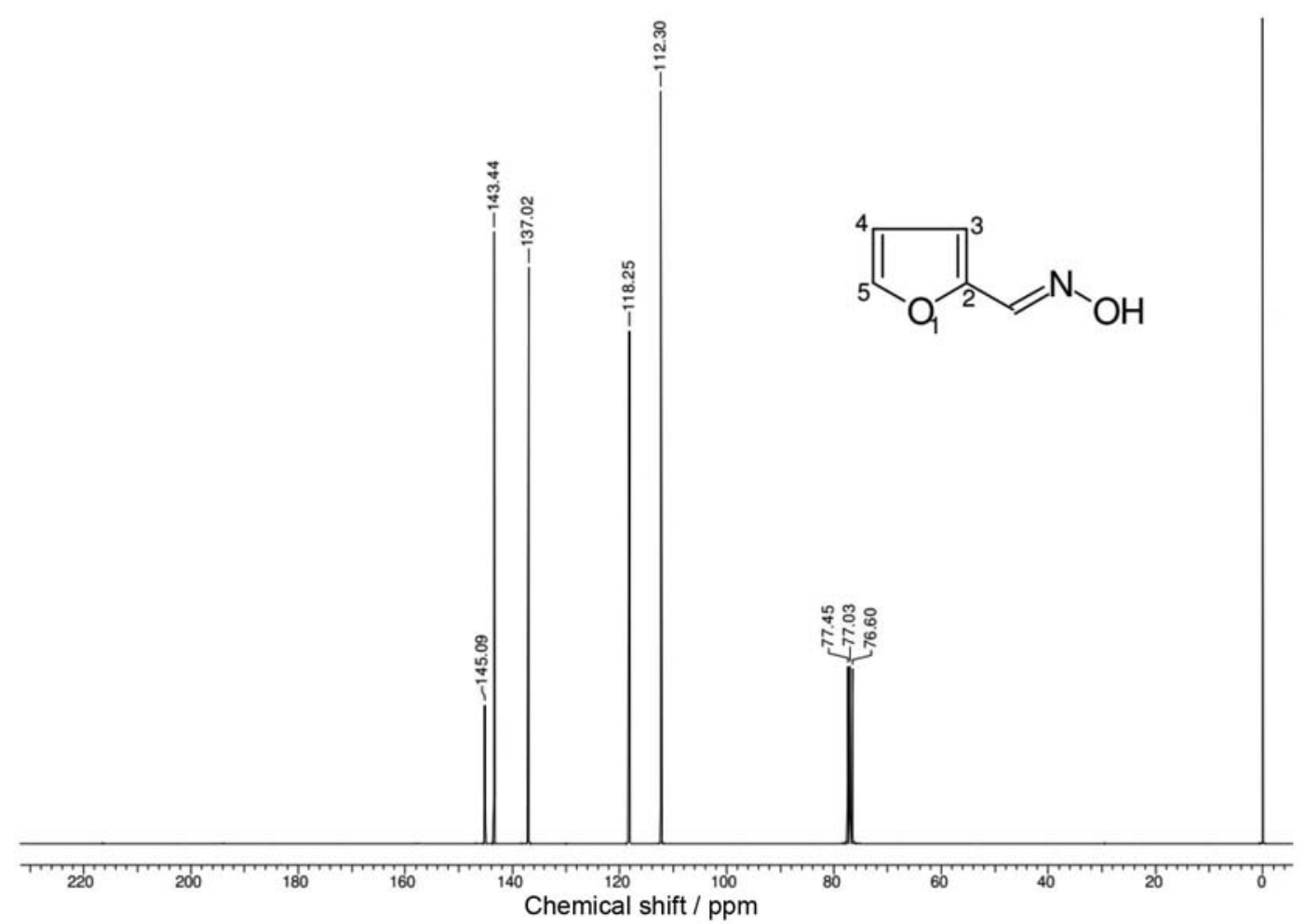

Figure S21. ${ }^{13} \mathrm{C}$ NMR $\left(75 \mathrm{MHz}, \mathrm{CDCl}_{3}\right)$ of furane-2-carboxyaldehyde oxime (23).

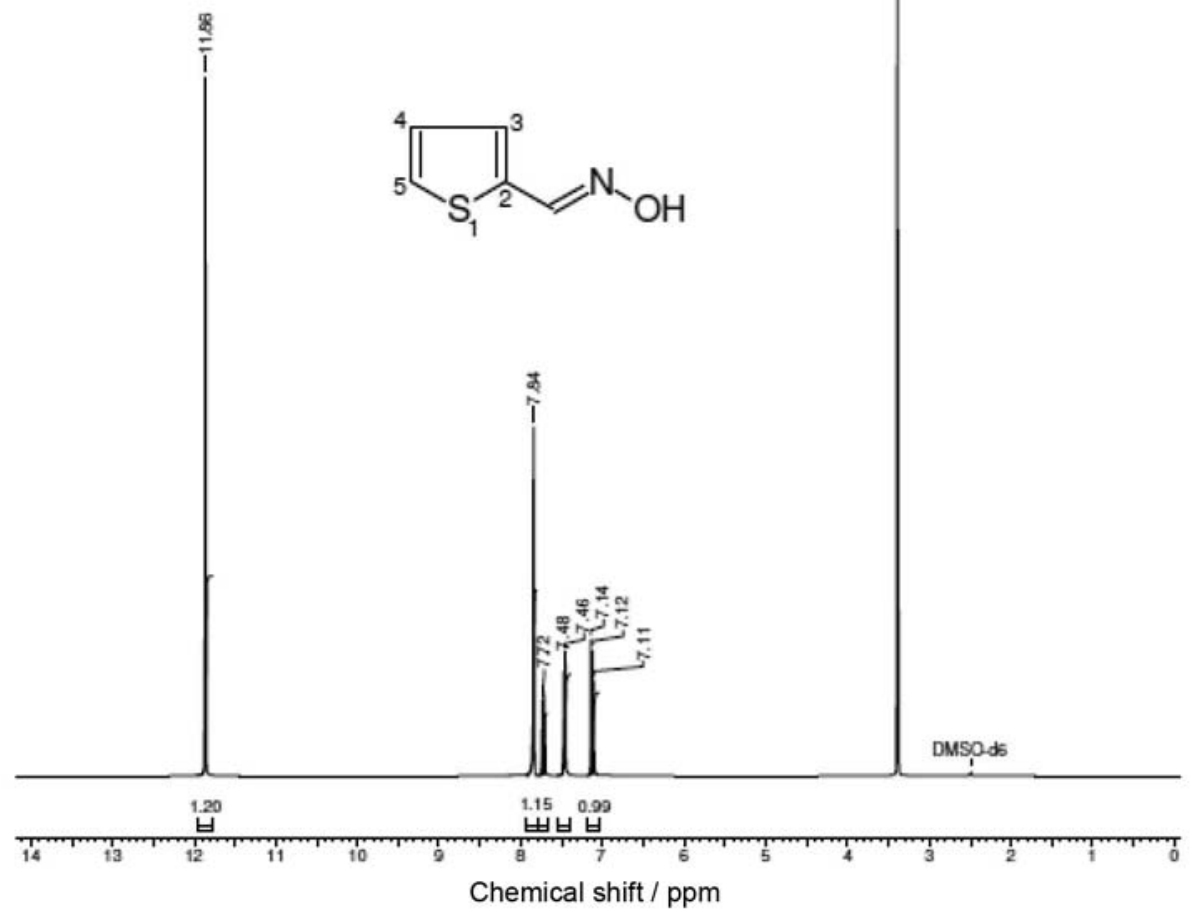

Figure S22. ${ }^{1} \mathrm{H}$ NMR (300 MHz, DMSO- $d_{6}$ ) of thiophene-2-carboxyladehyde oxime (24). 


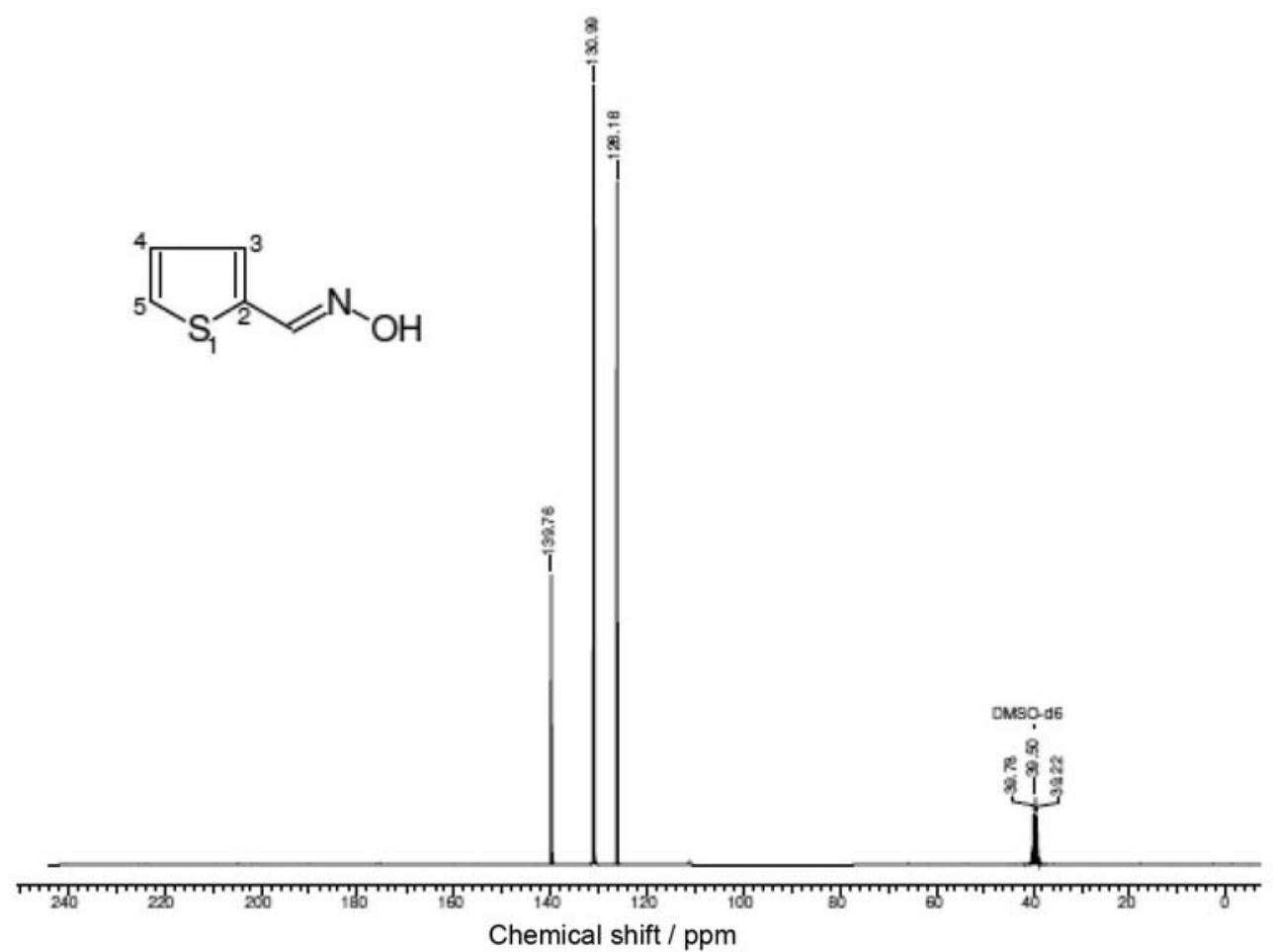

Figure S23. ${ }^{13} \mathrm{C}$ NMR (75 MHz, DMSO- $d_{6}$ ) of thiophene-2-carboxyladehyde oxime (24).

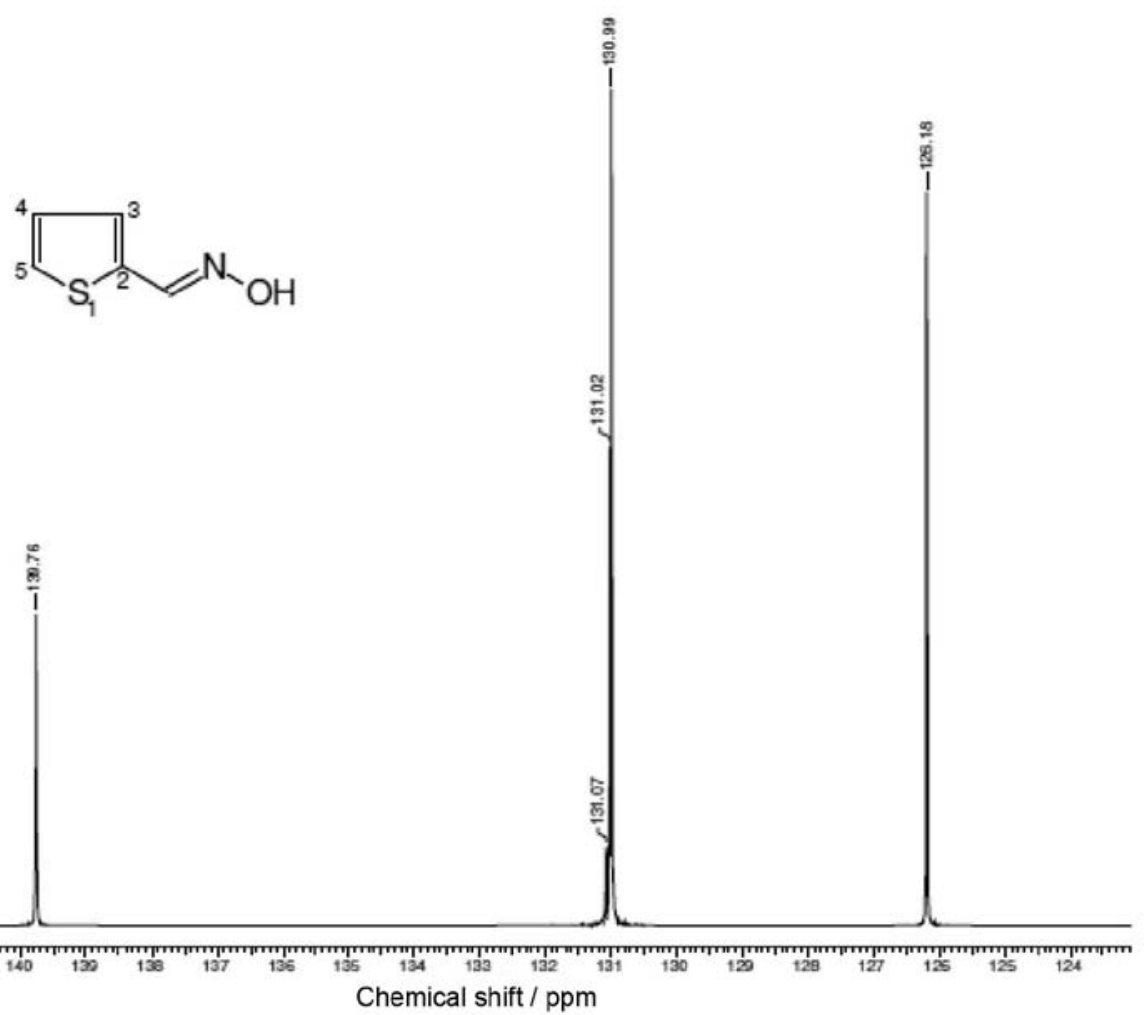

Figure S24. Expansion of ${ }^{13} \mathrm{C}$ NMR (75 MHz, DMSO- $d_{6}$ ) of thiophene-2-carboxyladehyde oxime (24). 


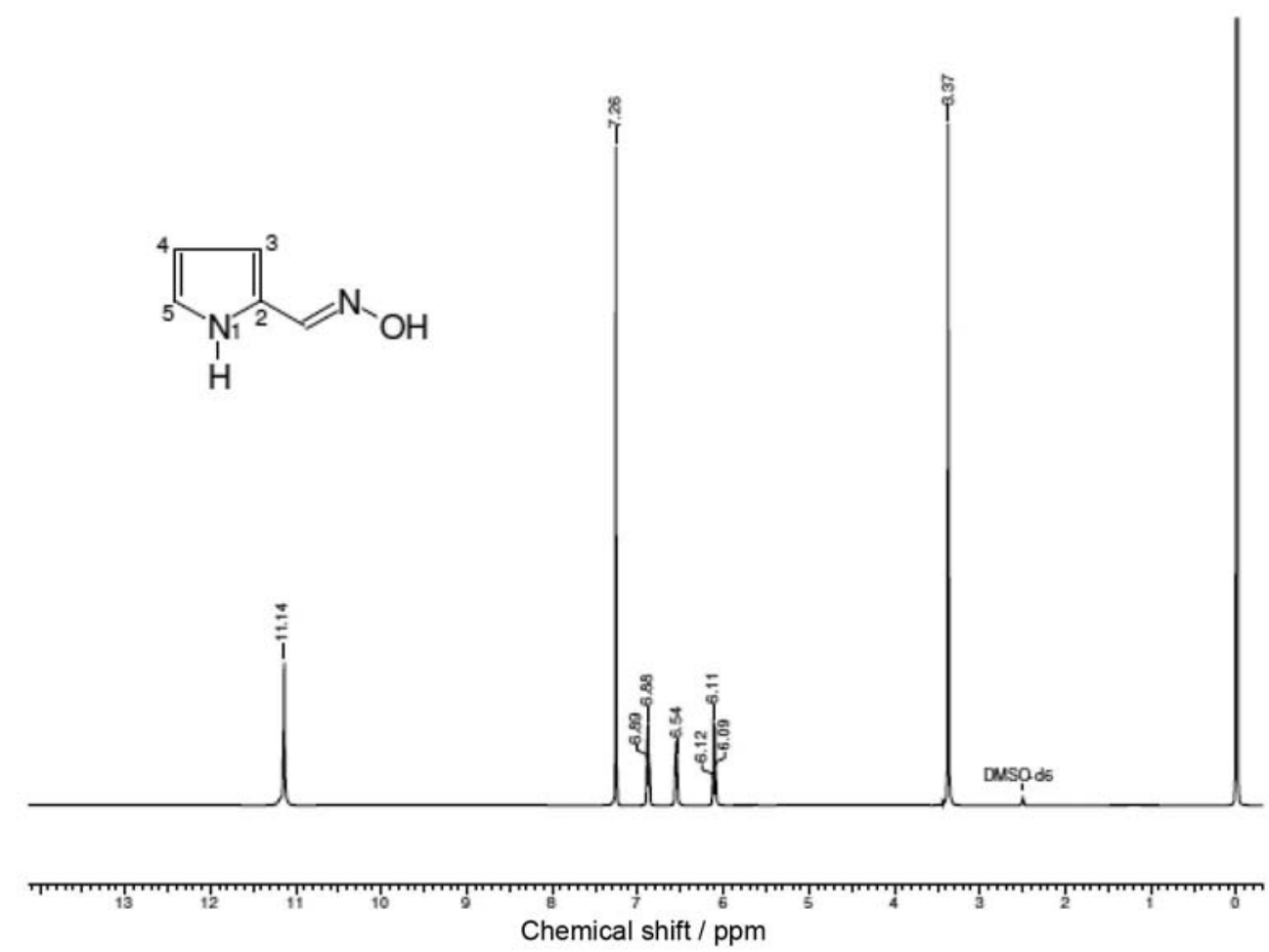

Figure S25. ${ }^{1} \mathrm{H}$ NMR (300 MHz, DMSO- $d_{6}$ ) of pyrrol-2-carboxyladehyde oxime (25).

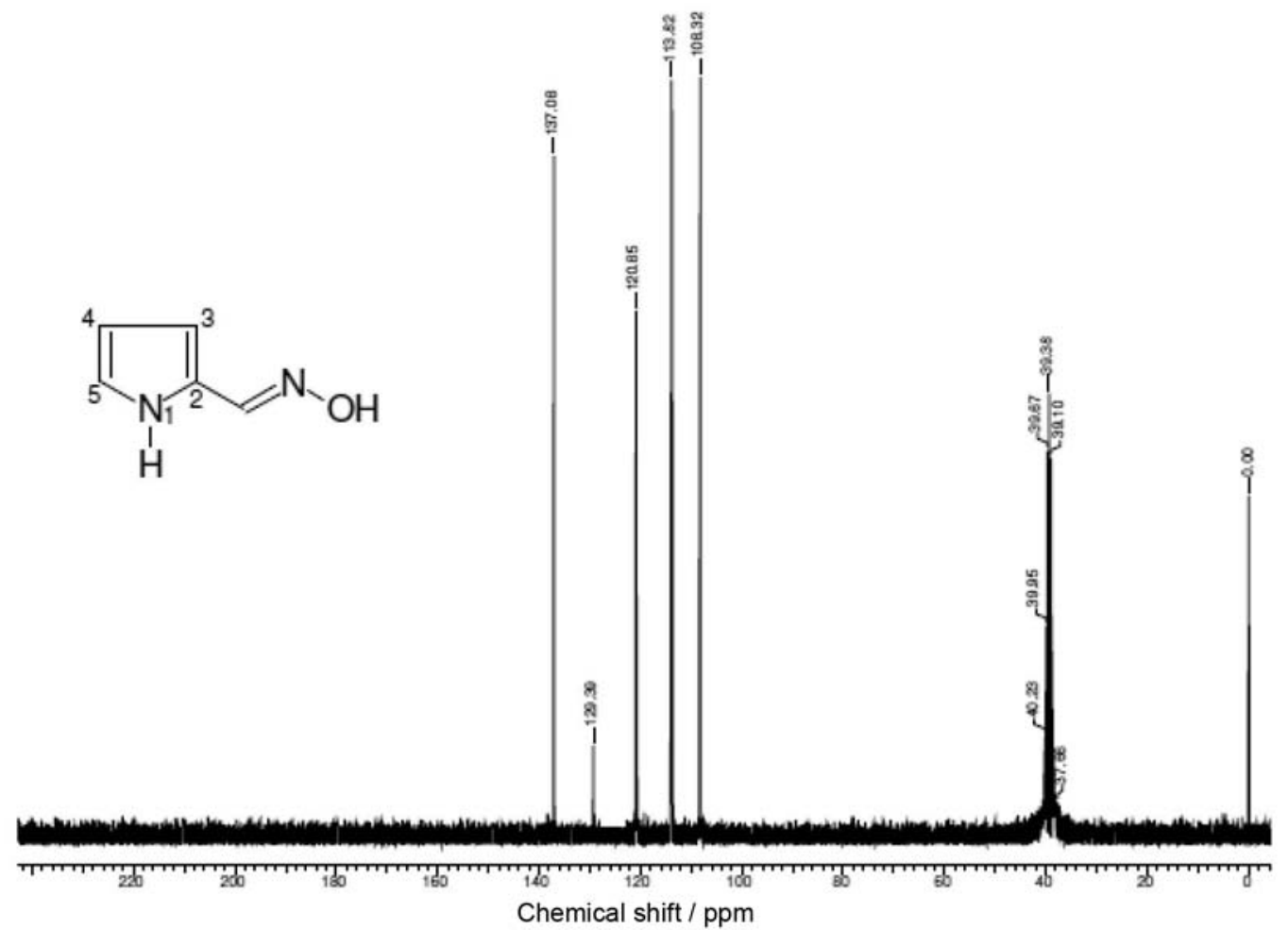

Figure S26. ${ }^{13} \mathrm{C}$ NMR (75 MHz, DMSO- $d_{6}$ ) of pyrrol-2-carboxyladehyde oxime (25). 
<smiles>Cn1ccnc1/C=N/O</smiles>

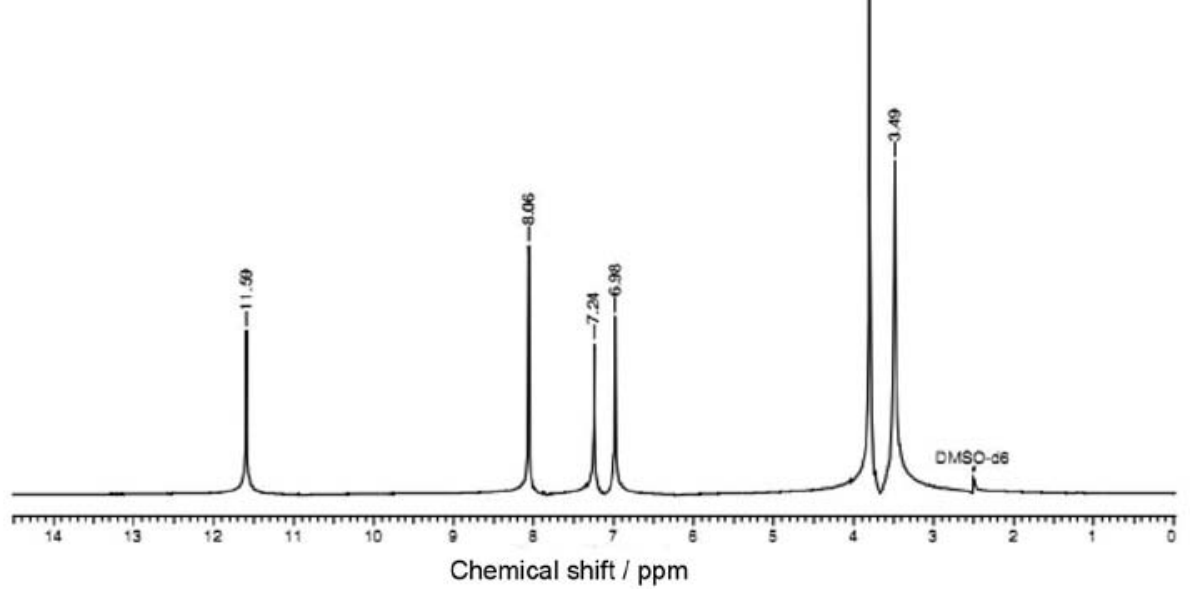

Figure S27. ${ }^{1} \mathrm{H}$ NMR (300 MHz, DMSO- $d_{6}$ ) of 1-methylimidazol-2-carboxyladehyde oxime (26).

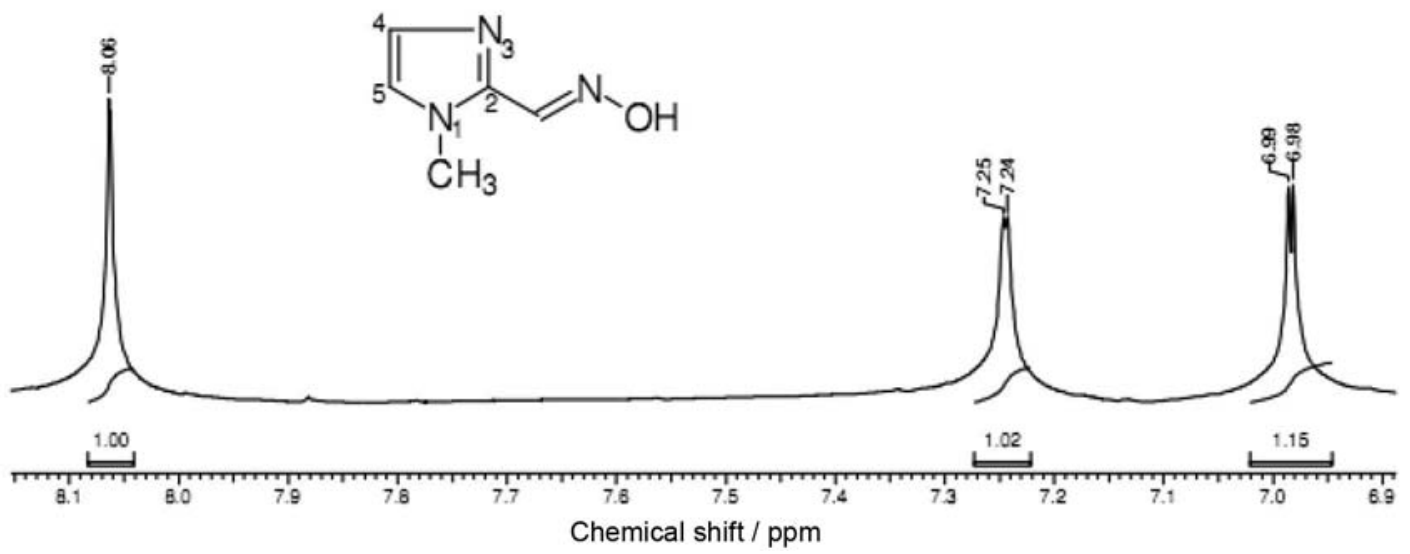

Figure S28. Expansion of ${ }^{1} \mathrm{H}$ NMR (300 MHz, DMSO- $d_{6}$ ) of 1-methylimidazol-2-carboxyladehyde oxime (26). 


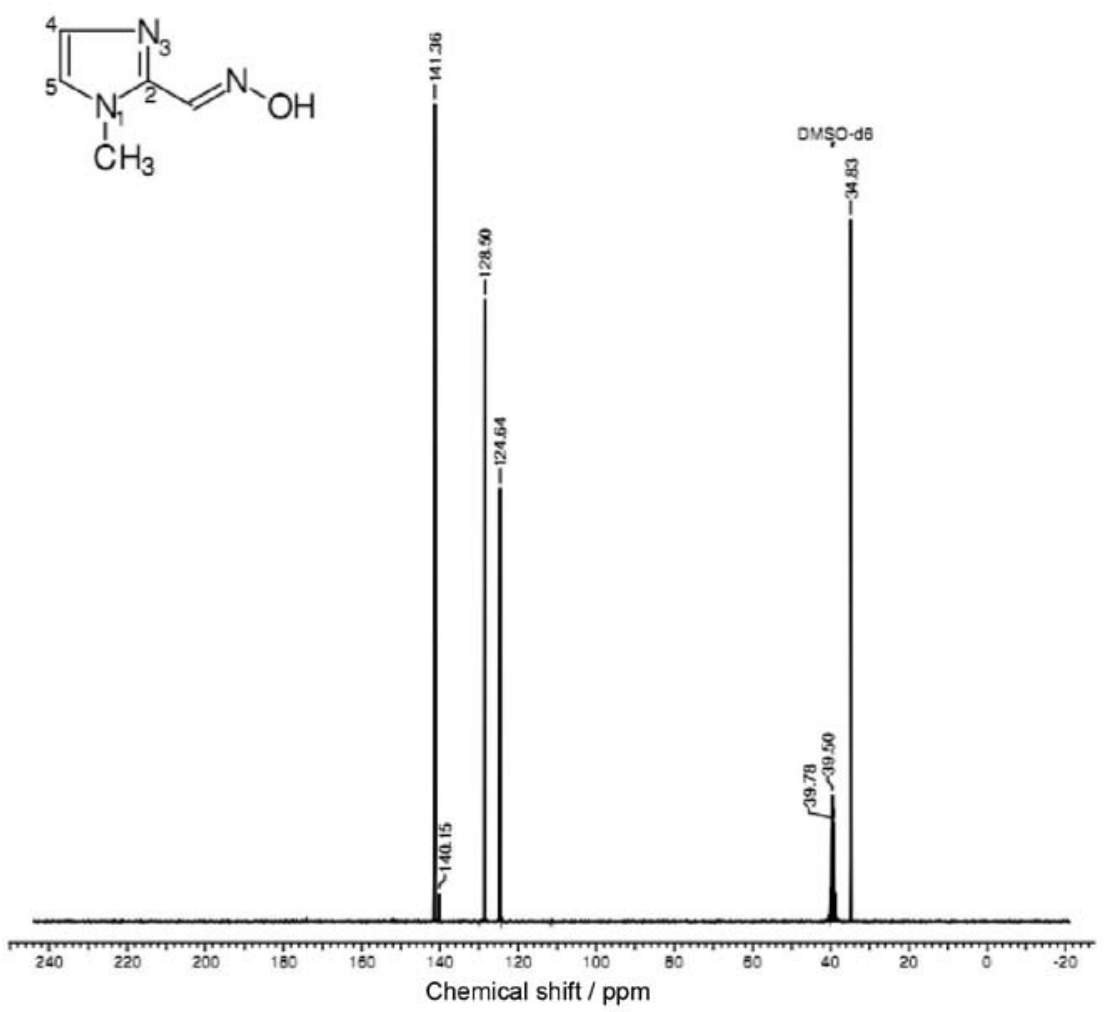

Figure S29. ${ }^{13} \mathrm{C}$ NMR (75 MHz, DMSO- $d_{6}$ ) of 1-methylimidazol-2-carboxyladehyde oxime (26).<smiles></smiles>

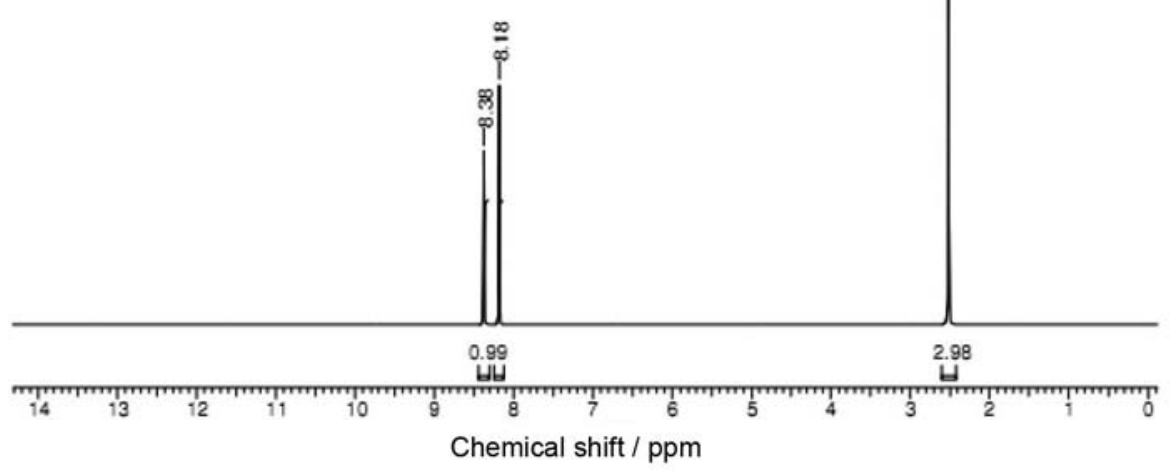

Figure S30. ${ }^{1} \mathrm{H}$ NMR (300 MHz, DMSO- $d_{6}$ ) of 4-methylimidazol-5-carboxyladehyde oxime (27). 


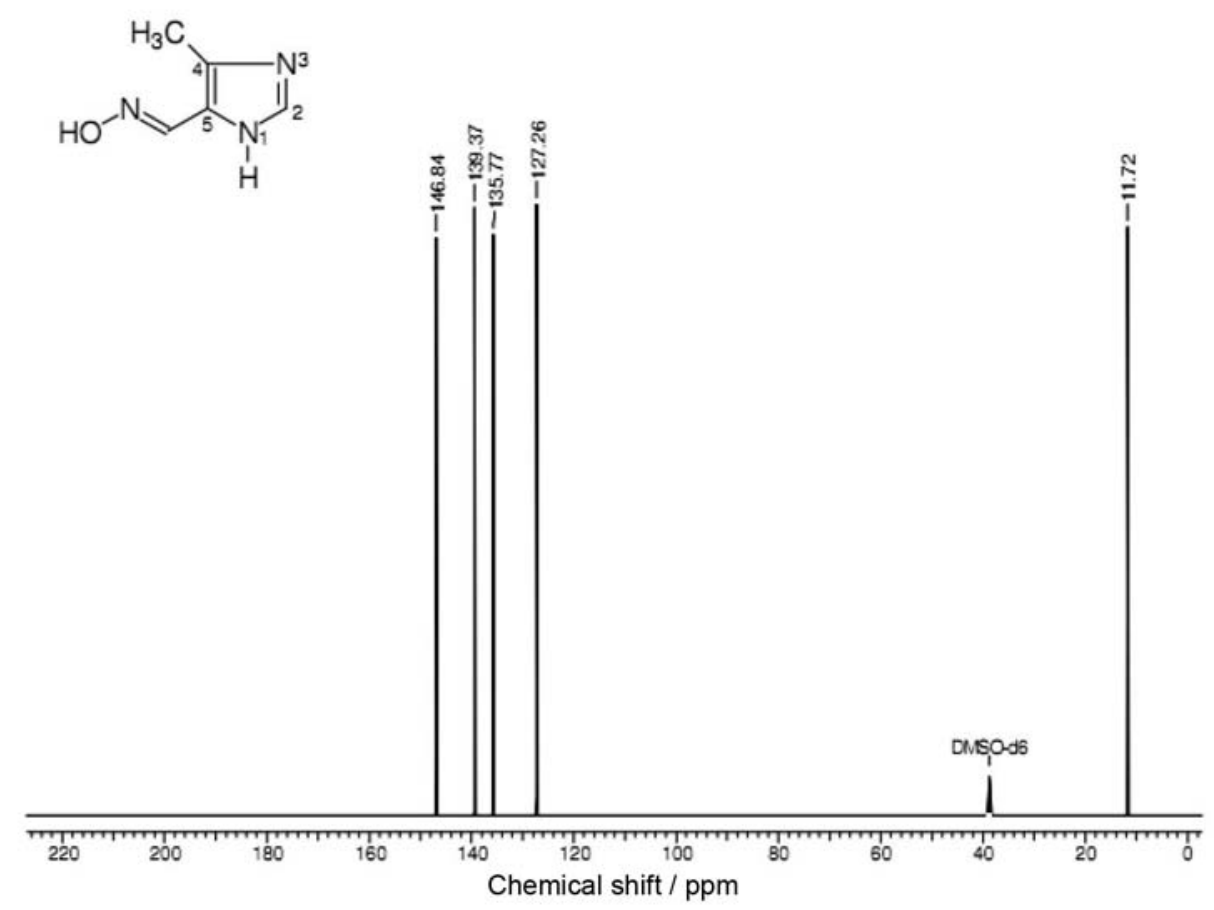

Figure S31. ${ }^{13} \mathrm{C}$ NMR (75 MHz, DMSO- $d_{6}$ ) of 4-methylimidazol-5-carboxyladehyde oxime (27).

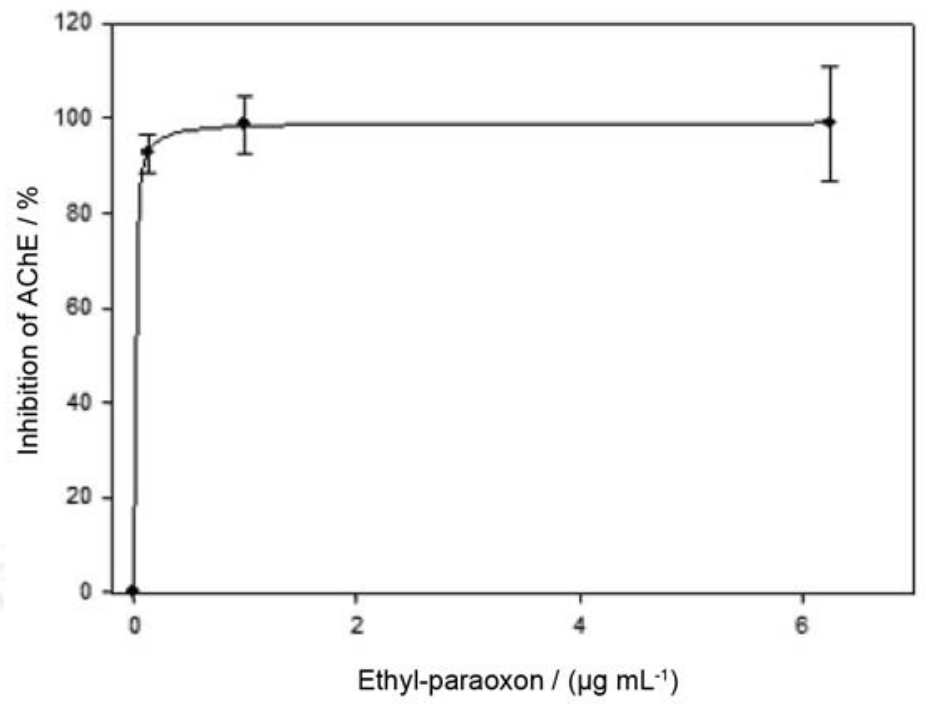

Figure S32. Graphic of ethyl-paraoxon inhibition on human AChE (in vitro). 